\title{
The Chloride Transporter $\mathrm{Na}^{+}-\mathrm{K}^{+}-\mathrm{Cl}^{-}$Cotransporter Isoform-1 Contributes to Intracellular Chloride Increases after In Vitro Ischemia
}

\author{
Brooks B. Pond, ${ }^{1}$ Ken Berglund, ${ }^{2}$ Thomas Kuner, ${ }^{3}$ Guoping Feng, ${ }^{2}$ George J. Augustine, ${ }^{2}$ and \\ Rochelle D. Schwartz-Bloom ${ }^{1,2}$ \\ Departments of ${ }^{1}$ Pharmacology and Cancer Biology and ${ }^{2}$ Neurobiology, Duke University Medical Center, Durham, North Carolina 27710, and ${ }^{3}$ Department \\ of Cell Physiology, Max-Planck-Institute for Medical Research, 69120 Heidelberg, Germany
}

\begin{abstract}
Ischemic episodes in the CNS cause significant disturbances in neuronal ionic homeostasis. To directly measure changes in intracellular $\mathrm{Cl}^{-}$concentration $\left(\left[\mathrm{Cl}^{-}\right]_{\mathrm{i}}\right)$ during and after ischemia, we used Clomeleon, a novel ratiometric optical indicator for $\mathrm{Cl}^{-}$. Hippocampal slices from adult transgenic mice expressing Clomeleon in hippocampal neurons were subjected to $8 \mathrm{~min}$ of oxygen-glucose deprivation (OGD) (an in vitro model for ischemia) and reoxygenated in the presence of glucose. This produced mild neuronal damage $3 \mathrm{~h}$ later that was prevented when the extracellular $\left[\mathrm{Cl}^{-}\right]$was maintained at $10 \mathrm{~mm}$ during reoxygenation. OGD induced a transient decrease in fluorescence resonance energy transfer within Clomeleon, indicating an increase in $\left[\mathrm{Cl}^{-}\right]_{\mathrm{i}}$. During reoxygenation, there was a partial recovery in $\left[\mathrm{Cl}^{-}\right]_{\mathrm{i}}$, but $\left[\mathrm{Cl}^{-}\right]_{\mathrm{i}}$ rose again $45 \mathrm{~min}$ later. To investigate sources of $\mathrm{Cl}^{-}$accumulation, we examined the effects of $\mathrm{Cl}^{-}$ transport inhibitors on the rises in $\left[\mathrm{Cl}^{-}\right]_{\mathrm{i}}$ during and after OGD. Bumetanide and furosemide, which inhibit $\mathrm{Cl}^{-}$influx through the $\mathrm{Na}^{+}-\mathrm{K}^{+}-\mathrm{Cl}^{-}$cotransporter isoform-1 (NKCC-1) and efflux through the $\mathrm{K}^{+}-\mathrm{Cl}^{-}$cotransporter isoform-2, were unable to inhibit the first rise in $\left[\mathrm{Cl}^{-}\right]_{\mathrm{i}}$, yet entirely prevented the secondary rise in $\left[\mathrm{Cl}^{-}\right]_{\mathrm{i}}$ during reoxygenation. In contrast, picrotoxin, which blocks the GABAgated $\mathrm{Cl}^{-}$channel, did not inhibit the secondary rise in $\left[\mathrm{Cl}^{-}\right]_{\mathrm{i}}$ after $\mathrm{OGD}$. $\left[\mathrm{Cl}^{-}\right]_{\mathrm{i}}$ increases during reoxygenation were accompanied by an increase in phosphorylation of NKCC-1, an indication of increased NKCC-1 activity after OGD. We conclude that NKCC-1 plays an important role in OGD-induced $\mathrm{Cl}^{-}$accumulation and subsequent neuronal damage.
\end{abstract}

Key words: oxygen-glucose deprivation; $\mathrm{Na}-\mathrm{K}-\mathrm{Cl}$ cotransporter; Clomeleon; bumetanide; furosemide; picrotoxin

\section{Introduction}

Cerebral ischemia, produced by a loss of blood supply to the brain, initiates a cascade of cellular events that lead to neuronal death in the hippocampus and other vulnerable brain regions. Ischemia is accompanied by disruption of neuronal ionic homeostasis, including significant increases in intracellular $\mathrm{Na}^{+}$, $\mathrm{Cl}^{-}$, and $\mathrm{Ca}^{2+}$, as well as increases in extracellular $\mathrm{K}^{+}$(for review, see Lipton, 1999). Whereas the roles of $\mathrm{Na}^{+}$and $\mathrm{Ca}^{2+}$ in ischemic damage have been examined extensively, relatively little is known about the role of elevated intracellular $\mathrm{Cl}^{-}$in neuronal injury. Previous studies indicate that intracellular $\mathrm{Cl}^{-}$concentrations $\left(\left[\mathrm{Cl}^{-}\right]_{\mathrm{i}}\right)$ rise in rat hippocampal neurons during oxygenglucose deprivation (OGD), an in vitro model for cerebral ischemia (Inglefield and Schwartz-Bloom, 1998; Galeffi et al., 2004). Reoxygenation causes $\left[\mathrm{Cl}^{-}\right]_{\mathrm{i}}$ to recover but is followed by a second prolonged rise in $\left[\mathrm{Cl}^{-}\right]_{\mathrm{i}}$. Because $\mathrm{GABA}_{\mathrm{A}}$-mediated hyper-

Received Dec. 18, 2004; revised Dec. 10, 2005; accepted Dec. 12, 2005.

This study was supported by National Institutes of Health Grants NS-28791 (R.D.S.-B.) and DA-15503 and MH73166 (G.J.A.), National Institutes of Health Fellowship NS-47828 (B.B.P.), and Japan Society for the Promotion of Science for Research Abroad (K.B.). We thank Dr. Biff Forbush for providing the R5 antibody against pNKCC-1 and Francesca Galeffi for her technical assistance.

Correspondence should be addressed to Dr. Rochelle D. Schwartz-Bloom, Department of Pharmacology and Cancer Biology, Box 3813, Duke University Medical Center, Durham, NC 27710. E-mail: schwa001@duke.edu. DOI:10.1523/JNEUROSCI.1421-05.2006

Copyright $\odot 2006$ Society for Neuroscience $\quad$ 0270-6474/06/261396-11\$15.00/0 polarizing inhibition depends on the transmembrane $\mathrm{Cl}^{-}$gradient, these rises in intracellular $\mathrm{Cl}^{-}$could cause GABA to be less inhibitory or even excitatory.

The $\mathrm{Na}^{+}-\mathrm{K}^{+}-\mathrm{Cl}^{-}$cotransporter isoform-1 (NKCC-1) appears to play an important role in ischemia-induced neuronal damage to neurons. NKCC- 1 is the isoform of NKCC that is expressed ubiquitously in the brain and in other tissues; NKCC-2, the other isoform of this transporter, is expressed only in the kidney (Russell, 2000). This transporter helps maintain the $\mathrm{Cl}^{-}$gradient in neurons and is hypothesized to influence neuronal excitability through the regulation of $\left[\mathrm{Cl}^{-}\right]_{\mathrm{i}}$ (Sung et al., 2000; Jang et al., 2001; Beck et al., 2003). For instance, NKCC-1 activity is believed to be primarily responsible for depolarizing responses produced by $\mathrm{GABA}_{\mathrm{A}}$ receptors in dorsal root ganglion neurons (Alvarez-Leefmans et al., 1988, 2001; Sung et al., 2000) and odorant receptors in olfactory receptor neurons (Reisert et al., 2005). Influx of ions through NKCC-1 is regulated by protein kinases, with phosphorylation of Ser/Thr residues causing a stimulation of NKCC-1 activity (Darman et al., 2002). Notably, high extracellular $\mathrm{K}^{+}$and glutamate receptor activation, factors that are known to participate in ischemic damage and excitotoxicity, induce phosphorylation and activation of NKCC-1 (Sun et al., 1998; Su et al., 2000; Schomberg et al., 2001). Based on these findings, it is possible that increased activity of NKCC- 1 contributes to the ischemia-induced accumulation of $\left[\mathrm{Cl}^{-}\right]_{\mathrm{i}}$, neuronal 
hyperexcitability, and subsequent neuronal injury. Consistent with this possibility, inhibitors of NKCC prevent OGD from damaging neurons in hippocampal slices (Pond et al., 2004) and in cultured cortical neurons (Beck et al., 2003). NKCC inhibitors also are neuroprotective after focal ischemia in vivo (Yan et al., 2001, 2003).

We investigated the role of NKCC- 1 and other $\mathrm{Cl}^{-}$transporters in the OGD-induced $\mathrm{Cl}^{-}$increase by monitoring $\left[\mathrm{Cl}^{-}\right]_{\mathrm{i}}$ in hippocampal slices from transgenic mice expressing Clomeleon, a genetically encoded, ratiometric $\mathrm{Cl}^{-}$indicator (Kuner and $\mathrm{Au}-$ gustine, 2000; Berglund et al., 2004). This indicator allowed us, for the first time, to measure $\left[\mathrm{Cl}^{-}\right]_{\mathrm{i}}$ throughout OGD and reoxygenation. The actions of NKCC inhibitors also allowed us to establish a role for $\mathrm{Cl}^{-}$transporters in the increase in $\left[\mathrm{Cl}^{-}\right]_{\mathrm{i}}$ produced after OGD. Our findings support the hypothesis that $\mathrm{Cl}^{-}$transporters contribute to ionic disruptions after OGD and therefore may be a key factor in the onset of neuronal injury produced by cerebral ischemia.

\section{Materials and Methods}

Clomeleon mice. Clomeleon is a fusion protein comprising two fluorophores, the $\mathrm{Cl}^{-}$-sensitive yellow fluorescent protein (YFP) and the $\mathrm{Cl}^{-}$insensitive cyan fluorescent protein (CFP). The physical proximity of the two fluorophores permits fluorescence resonance energy transfer (FRET). Because YFP fluorescence is quenched by $\mathrm{Cl}^{-}$, the ratio of the FRET-dependent emission of these fluorophores (YFP/CFP) varies in inverse proportion to the concentration of $\left[\mathrm{Cl}^{-}\right]_{\mathrm{i}}$ (Kuner and Augustine, 2000). Transgenic mouse lines that express Clomeleon were generated by placing Clomeleon under the control of neuronal-specific elements of the Thyl gene and randomly inserting this transgene into the genome of the C57BL/6 mouse (Berglund et al., 2004). Because of differences in the site of chromosomal integration, Clomeleon was expressed in subsets of neurons in different brain regions. Although each mouse line demonstrated different expression patterns, these expression patterns were inherited. In this study, homozygous mice from CLM line 1 were used, because these mice exhibited robust Clomeleon expression in hippocampal CA1 pyramidal neurons (Fig. 1).

Hippocampal slice preparation and oxygen-glucose deprivation. Hippocampal slices were prepared from adult 2- to 3-month-old Clomeleon mice for $\mathrm{Cl}^{-}$imaging and from 2- to 3-month-old wild-type C57BL/6 mice for $\mathrm{pH}$ imaging. Mice were anesthetized lightly with the inhalant anesthetic isoflurane and decapitated. Their brains were then removed rapidly from the skull while immersed in ice-cold physiological saline. This protocol was approved by the Duke University Animal Care and Use Committee. The physiological saline contained the following (in $\mathrm{mM}$ ): $119 \mathrm{NaCl}, 2.5 \mathrm{KCl}, 1.0 \mathrm{NaH}_{2} \mathrm{PO}_{4}, 1.3 \mathrm{MgCl}_{2}, 1.5 \mathrm{CaCl}_{2}, 26 \mathrm{NaHCO}_{3}$, and 11 glucose ( $\mathrm{pH} 7.4$ after bubbling with $95 \% \mathrm{O}_{2} / 5 \% \mathrm{CO}_{2}$ ). Coronal hippocampal slices (300 $\mu \mathrm{m}$ in thickness) were prepared using a Vibratome (St. Louis, MO). The slices were placed in an incubation chamber containing physiological saline that included $1 \mathrm{~mm}$ kynurenic acid to improve slice survival (Richerson and Messer, 1995). Slices were submerged $\sim 1 \mathrm{~cm}$ below the solution surface and incubated for $1 \mathrm{~h}$ at $33^{\circ} \mathrm{C}$. Subsequently, the slices were transferred to a superfusion chamber for optical imaging at $24^{\circ} \mathrm{C}$.

After a 5 min baseline recording period, slices were subjected to OGD by exposing the slices to glucose-free physiological saline equilibrated with $95 \% \mathrm{~N}_{2} / 5 \% \mathrm{CO}_{2}$ at $24^{\circ} \mathrm{C}$ for $8 \mathrm{~min}$. In some experiments, OGD was applied to slices bathed in saline in which $\mathrm{Cl}^{-}$was replaced by an equimolar concentration of gluconate. In the pilot experiments, we applied OGD to the hippocampal slices at various temperatures ranging from 22 to $37^{\circ} \mathrm{C}$. In mouse hippocampal slices, we found that OGD produces a severe insult, with widespread neuronal death occurring early during reoxygenation, at $37^{\circ} \mathrm{C}$ (B. B. Pond, unpublished observations). Thus, we chose OGD conditions that produce the same degree of mild neuronal damage in mouse slices (see Fig. 2), with the same time course, as reported previously in rat hippocampal slices subjected to OGD at either 27 or $36^{\circ} \mathrm{C}$ (Inglefield and Schwartz-Bloom, 1998; Galeffi et al.,
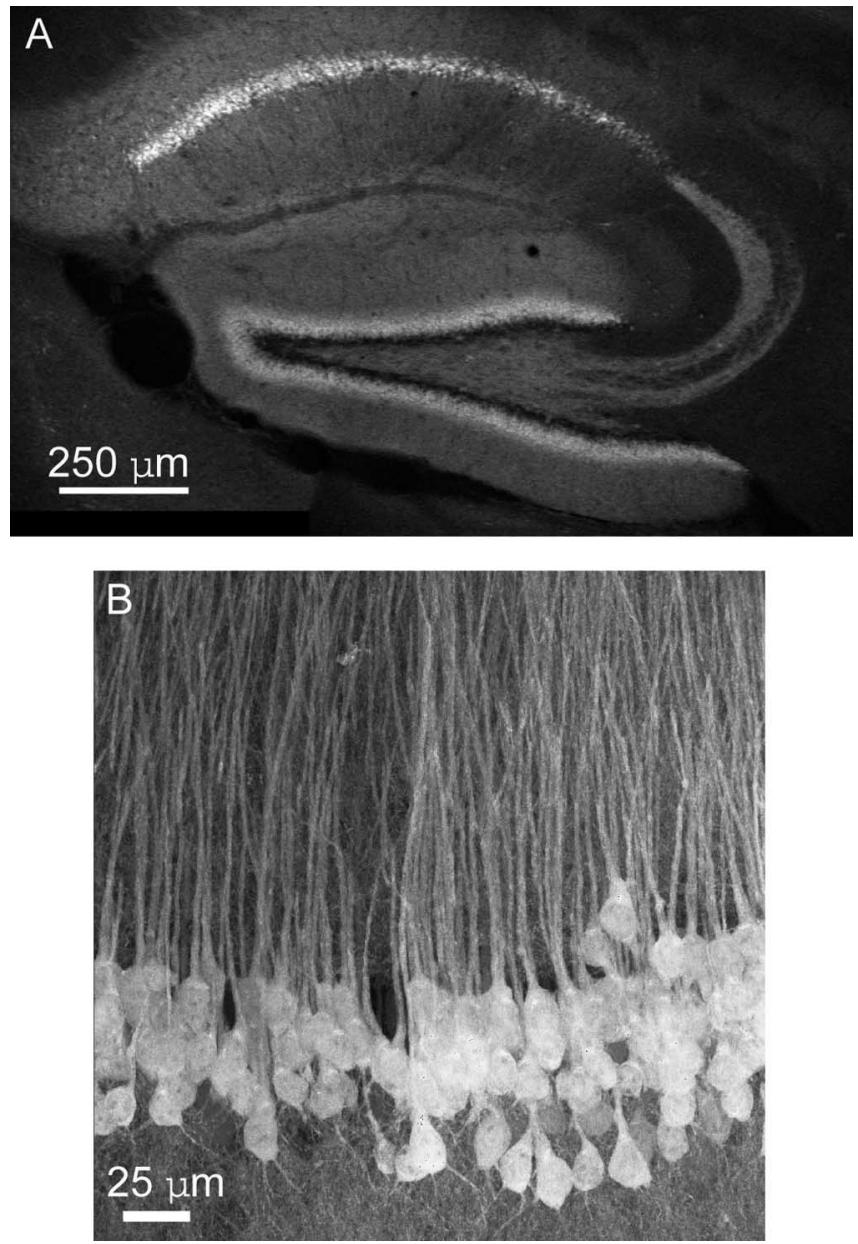

Figure 1. Clomeleon expression in hippocampal neurons from fixed slices. $\boldsymbol{A}$, Two-photon image of hippocampal neurons expressing Clomeleon from CLM line 1. $\boldsymbol{B}$, High-magnification confocal image of hippocampal area CA1 pyramidal neurons expressing Clomeleon. Note expression of Clomeleon throughout each cell, allowing clear visualization of apical and basilar dendrites.

2004). Control slices were kept in regular oxygenated physiological saline. After OGD, the slices were reoxygenated in the regular physiological saline (containing glucose) for $75 \mathrm{~min}$. In some experiments, the $\mathrm{Cl}^{-}$ transport inhibitors bumetanide $(10 \mu \mathrm{M})$, furosemide $(300 \mu \mathrm{M})$, or the $\mathrm{GABA}_{\mathrm{A}}$ antagonist picrotoxin $(100 \mu \mathrm{M})$ were added to the salines.

Intracellular loading of seminaphthorhodafluor-5F. At concentrations of $\mathrm{Cl}^{-}>10 \mathrm{~mm}$, Clomeleon is sensitive to $\mathrm{pH}$ as well as to $\left[\mathrm{Cl}^{-}\right]$(Kuner and Augustine, 2000). Given that OGD both acidifies cells (Katsura et al., 1992) and elevates $\left[\mathrm{Cl}^{-}\right]_{\mathrm{i}}$ (Inglefield and Schwartz-Bloom, 1998; Galeffi et al., 2004), it was important to monitor both variables. We assessed intracellular $\mathrm{pH}$ by using the $\mathrm{pH}$ indicator dye seminaphthorhodafluor-5F (SNARF-5F) (Invitrogen, Carlsbad, CA). This was loaded into neurons by suspending SNARF-5F AM ester in Pluronic F-127 (20\% w/v solution in DMSO; Invitrogen) and adding this solution to an oxygenated physiological saline, yielding a solution containing $17 \mu \mathrm{M}$ SNARF-5F AM. After the $1 \mathrm{~h}$ incubation period, hippocampal slices from adult male wild-type mice were exposed to the SNARF-5F AM solution for $30 \mathrm{~min}$ and then washed in oxygenated physiological saline (described above) for at least $15 \mathrm{~min}$ at $24^{\circ} \mathrm{C}$ before imaging was initiated.

Optical imaging in acute slices. Hippocampal slices were placed in a superfusion chamber (flow rate, $2 \mathrm{ml} / \mathrm{min}, 24^{\circ} \mathrm{C}$ ) on a precision $x-y$ stage mounted on an upright epifluorescence microscope (Eclipse E600-FN; Nikon, Melville, NY). Images were acquired with a cooled charge coupled device (CCD) camera (CoolSNAP fx or Cascade 512B; Photometrics, Tucson, AZ). A Nikon 40×, 0.8 numerical aperture water immersion objective was used to resolve individual cells during imaging. 
For Clomeleon imaging, fluorescence was elicited with light pulses 50 ms in duration controlled by a shutter (Uniblitz T132; Vincent Associates, Rochester, NY), and images were captured every minute over the recording period. Incident light from a $100 \mathrm{~W}$ mercury lamp (Osram, Munich, Germany) was band-pass filtered $(440 \pm 10 \mathrm{~nm}$ ) to optimize the excitation of CFP. Emitted light passed through a dichroic mirror (460 $\mathrm{nm}$ cutoff) and was bandpass filtered through one of two emission filters $(485 \pm 15 \mathrm{~nm}$ for CFP and $530 \pm 15 \mathrm{~nm}$ for YFP) alternated by a filter changer (MAC5000 System; Ludl Electronic Products, Hawthorne, NY). The excitation light shutter, filter wheel, and the CCD camera were controlled by RatioTool software (Inovision, Raleigh, NC) and a Linux personal computer.

Multiple regions of interest (ROIs) were drawn covering entire somata of individual CA1 pyramidal cells. Each experiment was repeated in at least four slices, and the number of replicates reported indicates the number of cells examined in all slices in a given condition. In Clomeleon slices, background fluorescence was measured in an area of the slice outside of the dendritic fields. The background-corrected intensity of fluorescence emitted at the two wavelengths was used to calculate a ratio in each ROI that is inversely proportional to $\left[\mathrm{Cl}^{-}\right]$(see Fig. $3 A$ ) (Kuner and Augustine, 2000). Calculation of a ratio eliminates problems associated with variations in indicator concentration and optical path length, allowing $\left[\mathrm{Cl}^{-}\right]_{\mathrm{i}}$ to be determined directly. The $\left[\mathrm{Cl}^{-}\right]_{\mathrm{i}}$ was calculated from the following relationship:

$$
\left[\mathrm{Cl}^{-}\right]_{\mathrm{i}}=K_{\mathrm{d}^{\prime}}\left[\left(R_{\max }-R\right) /\left(R-R_{\min }\right)\right],
$$

where $R$ is the measured 530/485 nm emission ratio, $R_{\min }$ and $R_{\max }$ represent the values when Clomeleon is either $\mathrm{Cl}^{-}$bound or $\mathrm{Cl}^{-}$free respectively, and $\mathrm{K}_{\mathrm{d}}{ }^{\prime}$ is the effective $\mathrm{Cl}^{-}$dissociation constant of Clomeleon. The constants $R_{\min }, R_{\max }$, and $K_{\mathrm{d}}{ }^{\prime}$ were determined in situ using solutions of known concentrations of $\mathrm{Cl}^{-}$. The $\mathrm{Cl}^{-} / \mathrm{OH}^{-}$antiporter tributyltin chloride and the $\mathrm{K}^{+} / \mathrm{H}^{+}$ionophore nigericin were used to remove transmembrane $\mathrm{H}^{+} / \mathrm{OH}^{-}$and $\mathrm{Cl}^{-}$gradients, as by Berglund et al. (2004). Autofluorescence was measured in wild-type slices and was found to be $\sim 1 \%$ as large as Clomeleon fluorescence at each emission wavelength, so it was unnecessary to correct Clomeleon emission signals for autofluorescence.

For pH imaging, SNARF-5F-loaded slices were excited with 100-msduration light pulses $(540 \pm 10 \mathrm{~nm})$, and images were captured every minute over the recording period. Emitted light passed through a dichroic mirror (565 nm cutoff) and was bandpass filtered by the two emission filters $(580 \pm 30$ and $620 \pm 30 \mathrm{~nm})$ alternated by the filter changer. The background-corrected intensity of fluorescence emitted at the two wavelengths was used to calculate a ratio that is directly proportional to $\mathrm{pH}$. The calibration curve and the constants $R_{\min }, R_{\max }$, and $K_{\mathrm{d}}$ were determined in vitro as by Bonnet et al. (1998). Briefly, standard $\mathrm{pH}$ solutions were used containing $2 \mu \mathrm{M}$ SNARF-5F carboxylic acid dissolved in a saline containing the following (in mM): $10 \mathrm{NaCl}, 100 \mathrm{KCl}, 1.3$ $\mathrm{MgSO}_{4}, 1.25 \mathrm{KH}_{2} \mathrm{PO}_{4}, 26 \mathrm{Na}-\mathrm{HEPES}$, and 11 glucose. The $\mathrm{pH}$ was adjusted with $\mathrm{HCl}$ and $\mathrm{KOH}$. Titration of SNARF-5F yielded a sigmoidal plot (see Fig. $3 B$ ) that was described by the following equation: $\mathrm{pH}=K_{\mathrm{d}}$ $+\log \left[\left(R-R_{\min }\right) /\left(R_{\max }-R\right)\right]$, where $R$ is the measured $620 / 580 \mathrm{~nm}$ emission ratio, $R_{\min }$ and $R_{\max }$ represent the values when SNARF-5F is either $\mathrm{H}^{+}$bound or $\mathrm{H}^{+}$free respectively, and $K_{\mathrm{d}}$ is the effective $\mathrm{H}^{+}$ dissociation constant of SNARF-5F.

Histology. Hippocampal slices were collected after $3 \mathrm{~h}$ of reoxygenation and fixed overnight by immersion in phosphate-buffered $4 \%$ paraformaldehyde, $\mathrm{pH}$ 7.4. In some experiments, during reoxygenation, the $\mathrm{Cl}^{-}$ concentration in the superfusion saline was lowered to $10 \mathrm{~mm}$. Slices were placed in cryoprotectant (30\% sucrose in phosphate buffer and $0.1 \%$ sodium azide) for at least $12 \mathrm{~h}$. Hippocampi were dissected from the slice, frozen, and sectioned into $20 \mu \mathrm{m}$ sections using a cryostat. To eliminate variability attributable to slicing damage, only sections from the inner region of the slices ( $60 \mu \mathrm{m}$ deep on either side) were collected on gelatincoated microscope slides and analyzed. Sections were stained with cresyl violet for examination of cell viability.

Histological integrity was determined in a "blind" manner, and a damage score was assigned to each hippocampal slice using the following rating scale as described by Pond et al. (2004): 0, 0\% of neurons are abnormal (area CA1 neurons have intact cell boundaries, clear cytoplasm, and clearly visible nucleoli); $1,<25 \%$ of neurons are abnormal (abnormal cells are slightly shrunken); $2,25-50 \%$ of neurons are abnormal; $3,50-75 \%$ of neurons are abnormal; $4,>75 \%$ of neurons are abnormal (abnormal cells are shrunken, exhibiting some pyknosis); and 5, $100 \%$ of neurons are abnormal (hippocampi exhibit extensive pyknosis and destruction of area CA1).

To determine the effect of elevated $\left[\mathrm{Cl}^{-}\right]_{\mathrm{i}}$ on neuronal morphology, slices were exposed to saline containing 6 or $12 \mathrm{mM} \mathrm{Cl}^{-}$in conjunction with $20 \mu \mathrm{M}$ tributyltin and $20 \mu \mathrm{M}$ nigericin to clamp $\left[\mathrm{Cl}^{-}\right]_{\mathrm{i}}$ at the extracellular levels (see above). Six millimolar $\mathrm{Cl}^{-}$reflects the resting $\left[\mathrm{Cl}^{-}\right]_{\mathrm{i}}$, and $12 \mathrm{~mm}$ reflects the peak rise in $\left[\mathrm{Cl}^{-}\right]_{\mathrm{i}}$ after OGD (see Fig. $5 F$ ). Lowered $\left[\mathrm{Cl}^{-}\right]$was achieved by replacing the remaining chloride in the physiological saline with gluconate. After $2.25 \mathrm{~h}$, slices were fixed and processed as described above. This exposure time was chosen to reflect the time during which neurons typically experience a rise in $\left[\mathrm{Cl}^{-}\right]_{\mathrm{i}}$ and suffer injury after OGD.

For analysis of Clomeleon expression in the hippocampus, homozygous male CLM 1 mice ( $\sim 2$ months old) were killed with an overdose of halothane and transcardially perfused with $0.1 \mathrm{M}$ PBS, pH 7.4, followed by $50 \mathrm{ml}$ of $4 \%$ paraformaldehyde in PBS. Brains were removed and stored at $4^{\circ} \mathrm{C}$ in $4 \%$ paraformaldehyde overnight. Brains were transferred to cryoprotectant (30\% sucrose in PBS) until sectioned. Frozen brains were sectioned parasagittally at $40 \mu \mathrm{m}$ thickness, and sections were mounted onto slides and allowed to dry. Brain tissue was dehydrated with a sequence of ethanol solutions.

These fixed sections were examined with a two-photon microscope equipped with a laser scanning system (ULTIMA; Prairie Technologies, Middleton, WI). Clomeleon fluorescence was elicited with $880 \mathrm{~nm}$ light from a diode-pumped laser (Chameleon; Coherent, Santa Clara, CA). Emitted light was split by a dichroic mirror (cutoff at $515 \mathrm{~nm}$ ) and bandpass filtered through two emission filters ( $485 \pm 15 \mathrm{~nm}$ for CFP and $530 \pm 15 \mathrm{~nm}$ for YFP; Cameleons two-filter set 71007; Chroma Technologies, Rockingham, VT) and collected by photomultipliers. Laser scanning and photomultipliers were controlled with PrairieView software (Prairie Technologies, Middleton, WI) in a personal computer. For confocal imaging, confocal image stacks of paraformaldehyde-fixed brain slices were acquired with a Leica (Nussloch, Germany) TCS SP2 laser scanning microscope equipped with an acousto-optical beam splitter. Leica software was used to generate projections of the image stack.

Measurement of pNKCC-1 and NKCC-1 protein expression. To determine the effect of OGD on NKCC-1 protein, hippocampal slices were prepared from 2- to 3-month-old male C57BL/6 mice and subjected to OGD as described above. Slices were reoxygenated in the regular physiological saline (containing glucose) for up to $2 \mathrm{~h}$ at $24^{\circ} \mathrm{C}$. Tissue samples were prepared using a method modified from Schomberg et al. (2003). Hippocampi were dissected from acute slices, and several hippocampal slices from each treatment group (control, OGD plus $1 \mathrm{~h}$ reoxygenation, or OGD plus $2 \mathrm{~h}$ reoxygenation) were combined in ice-cold physiological saline. Hippocampi were homogenized with a glass-Teflon homogenizer in ice-cold PBS containing phosphatase inhibitors ( $100 \mathrm{~mm} \mathrm{NaF}, 10 \mathrm{~mm}$ $\mathrm{Na}_{4} \mathrm{P}_{2} \mathrm{O}_{7}, 2 \mathrm{mM} \mathrm{NaVO}_{3}$, and $0.2 \mu \mathrm{M}$ microcystin) and a protease inhibitor cocktail (1:200; Sigma, St. Louis, MO). Cellular debris was removed by centrifugation at $420 \times g$ for $5 \mathrm{~min}$ at $4^{\circ} \mathrm{C}$. The resulting supernatant was collected and spun at $10,000 \times g$ in a microcentrifuge for $15 \mathrm{~min}$ at $4^{\circ} \mathrm{C}$ to remove mitochondria. The supernatant was spun again at $125,000 \times g$ at $4^{\circ} \mathrm{C}$ for $30 \mathrm{~min}$, and the resulting membrane pellet was frozen at $-80^{\circ} \mathrm{C}$.

Membrane pellets were resuspended in 1\% SDS in PBS for $30 \mathrm{~min}$ at $24^{\circ} \mathrm{C}$, and the protein content of samples was determined using a protein assay kit (Bio-Rad, Hercules, CA). Samples were denatured in SDS reducing buffer (Laemmli's buffer) for $30 \mathrm{~min}$ at $55^{\circ} \mathrm{C}$ before gel electrophoresis. Equal amounts of protein samples were loaded onto 6\% Tris-glycine gradient gels (Invitrogen). Proteins were separated by SDS-PAGE and transferred to polyvinyl difluoride membrane (Millipore, Billerica, MA).

After two rinses with water, membranes were incubated in blocking solution (7.5\% milk in Tris-buffered saline with $0.1 \%$ Tween 20$)$ for $2 \mathrm{~h}$ at $24^{\circ} \mathrm{C}$. Membranes first were blotted for pNKCC- 1 by incubation with 

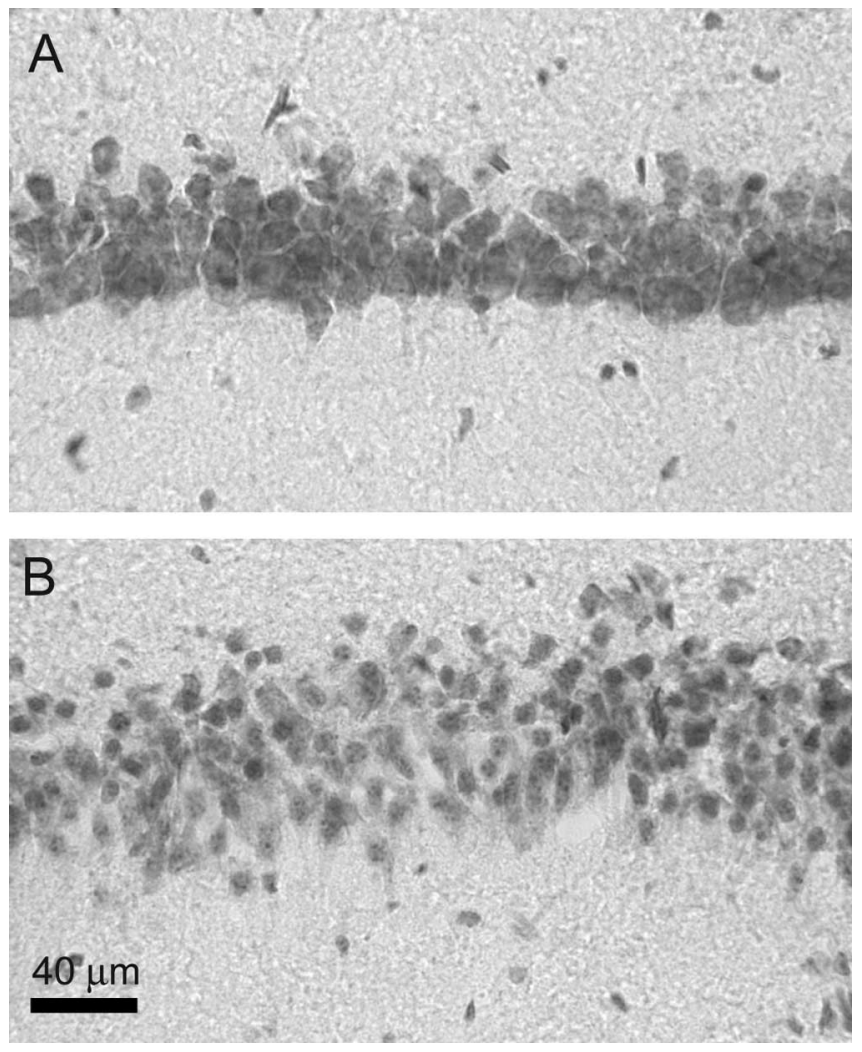

Figure 2. Effect of $O G D$ on area CA1 morphology. $A$, Area CA1 of a hippocampal slice not exposed to $O G D$ but submerged in regular physiological saline for $3 \mathrm{~h}$. $\boldsymbol{B}$, Area CA1 of a hippocampal slice exposed to 8 min of OGD and reoxygenated in the presence of glucose for $3 \mathrm{~h}$.

the $\mathrm{R} 5$ rabbit polyclonal antibody against a diphosphopeptide containing T184 and T189 of NKCC1 (pNKCC-1, 1:4000; kind gift from Biff Forbush, Yale University, New Haven, CT) and mouse anti- $\beta$ III tubulin antibody (1:3000; Promega, Madison, WI) overnight at $4^{\circ} \mathrm{C}$. Membranes were exposed to horseradish peroxidase-linked secondary antibodies (anti-mouse and anti-rabbit antibodies; Amersham Biosciences, Piscataway, NJ) for $1 \mathrm{~h}$ at $24^{\circ} \mathrm{C}$. Protein bands were detected by enhanced chemiluminescence on film.

To determine total NKCC-1 expression, the same membrane blots were stripped with $7 \mathrm{~m}$ guanidine- $\mathrm{HCl}$ containing $10 \mathrm{~mm}$ dithiothreitol, washed, and reprobed for NKCC-1 protein. Membranes were incubated in blocking solution overnight at $4^{\circ} \mathrm{C}$ and incubated with a T4 mouse monoclonal antibody that recognizes NKCC-1 (1:1000; Developmental Studies Hybridoma Bank, University of Iowa, Iowa City, IA) in the brain for $2 \mathrm{~h}$ at $24^{\circ} \mathrm{C}$. Membranes were exposed to a horseradish peroxidaselinked secondary antibody (Amersham Biosciences) for $1 \mathrm{~h}$ at $24^{\circ} \mathrm{C}$. All films were scanned, and data were digitized using Gel Doc (Bio-Rad) and expressed as optical density units per area.

\section{Results}

Exposure of hippocampal slices to $8 \mathrm{~min}$ of OGD followed by $3 \mathrm{~h}$ of reoxygenation produced consistent abnormalities in the morphology of cells in the area CA1 (Fig. 2). Pyramidal neurons were shrunken and slightly pyknotic, yet massive necrosis was not observed. This mild neuronal injury was comparable with that produced by OGD in rat hippocampal slices at room temperature (Galeffi et al., 2004), conditions that cause a complete cessation of evoked field potentials during OGD that is reversed during reoxygenation (Inglefield and Schwartz-Bloom, 1998). Thus, the conditions for OGD used here in the mouse hippocampal slice permits the use of optical imaging to measure early functional
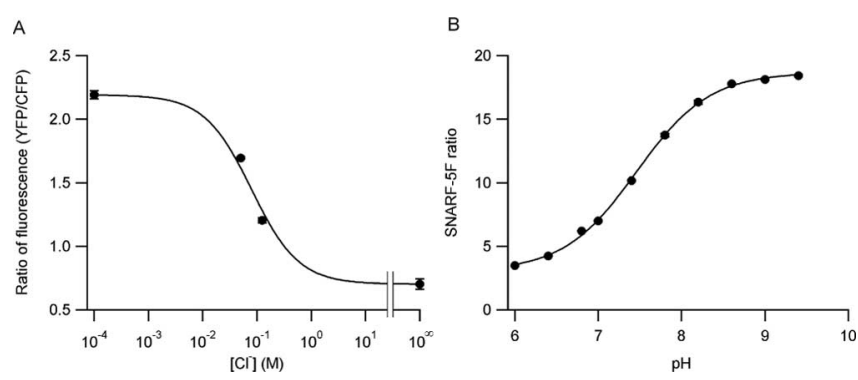

Figure 3. Calibration of Clomeleon and SNARF-5F. A, Calibration curve for Clomeleon, relating the ratio of the FRET-dependent emission of Clomeleon (YFP/CFP) to $\left[\mathrm{Cl}^{-}\right]_{\mathrm{i}}$. B, Sigmoidal plot resulting from calibration of SNARF-5F, relating the ratio of SNARF-5F emission (620/580 $\mathrm{nm}$ ) to intracellular $\mathrm{pH}$.
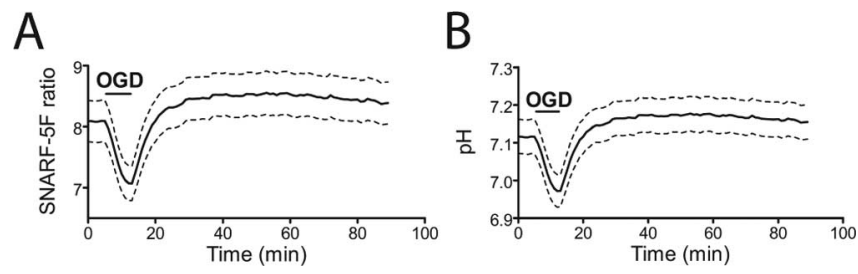

Figure 4. Imaging SNARF-5F in hippocampal slices exposed to OGD. A, OGD-induced changes in SNARF-5F fluorescence at $620 / 580 \mathrm{~nm}$. Images were captured every minute over a $90 \mathrm{~min}$ recording period. After a $5 \mathrm{~min}$ baseline recording period, slices were subjected to $8 \mathrm{~min}$ of $O G D$ and reoxygenated in the presence of glucose. Data are expressed as the average ratio value from 24 cells, and SEs are represented as dashed lines. B, OGD-induced changes in intracellular pH. Emission ratios presented in $\boldsymbol{A}$ were converted to $\mathrm{pH}$ using Equation 1. Data are expressed as the average $\mathrm{pH}$ value from 24 cells, and SEs are represented as dashed lines.

changes in neurons during reoxygenation, in the absence of frank neuronal degeneration.

\section{Effect of OGD on intracellular $\mathrm{pH}$}

Depriving cells of oxygen and glucose causes an accumulation of lactic acid that acidifies intracellular pH (Katsura et al., 1992). Such changes could affect our measurements of $\left[\mathrm{Cl}^{-}\right]_{\mathrm{i}}$ because Clomeleon is sensitive to protons, although Clomeleon emission is virtually insensitive to $\mathrm{pH}$ at $\left[\mathrm{Cl}^{-}\right]_{\mathrm{i}}<10 \mathrm{~mm}$ (Kuner and Augustine, 2000). To investigate how changes in $\mathrm{pH}$ influence $\left[\mathrm{Cl}^{-}\right]_{\mathrm{i}}$ measurements reported by Clomeleon, we measured intracellular $\mathrm{pH}$ with SNARF-5F, a ratiometric optical indicator for $\mathrm{pH}$. Oxygen-glucose deprivation produced a transient decrease in SNARF-5F fluorescence at $620 \mathrm{~nm}$, resulting in a decrease in the ratio of emission at $620 / 580 \mathrm{~nm}$ (see Fig. $4 A$ ). The calibration curve of Figure $3 B$ was used to convert these values to intracellular $\mathrm{pH}$, yielding the time course of OGD-induced acidification of the hippocampal area CA1 neurons (Fig. $4 B$ ). Resting $\mathrm{pH}$ in these neurons was $7.12 \pm 0.05$, consistent with values derived by other methods (Boyarsky et al., 1988; Tombaugh, 1994; Bonnet et al., 1998; Diarra et al., 1999). Oxygen-glucose deprivation caused a small but significant decrease in intracellular $\mathrm{pH}(0.14 \pm 0.04 \mathrm{pH}$ units; $p<0.05$ vs baseline $\mathrm{pH}$, ANOVA followed by Tukey's multiple comparison test; $n=26$ ), whereas reoxygenation caused intracellular $\mathrm{pH}$ to recover to baseline levels and remain stable thereafter (Fig. 4B). The small decrease in $\mathrm{pH}$ observed during OGD reflects the rather mild injury produced under our conditions.

The small decrease in $\mathrm{pH}$ that occurs during OGD could alter Clomeleon fluorescence and, thereby, influence $\left[\mathrm{Cl}^{-}\right]_{\mathrm{i}}$ measurements during this time. We took this into account by introducing a $\mathrm{pH}$ sensitive term into the fit of Equation 1 depicted in Figure 

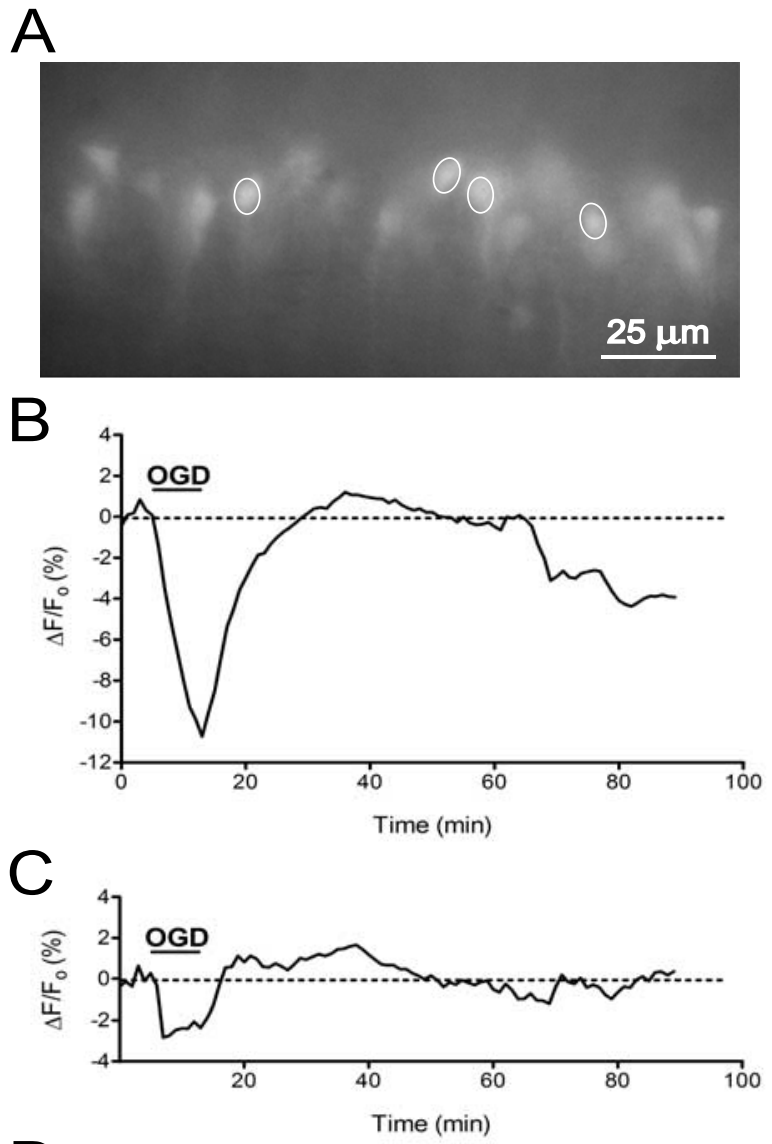

D
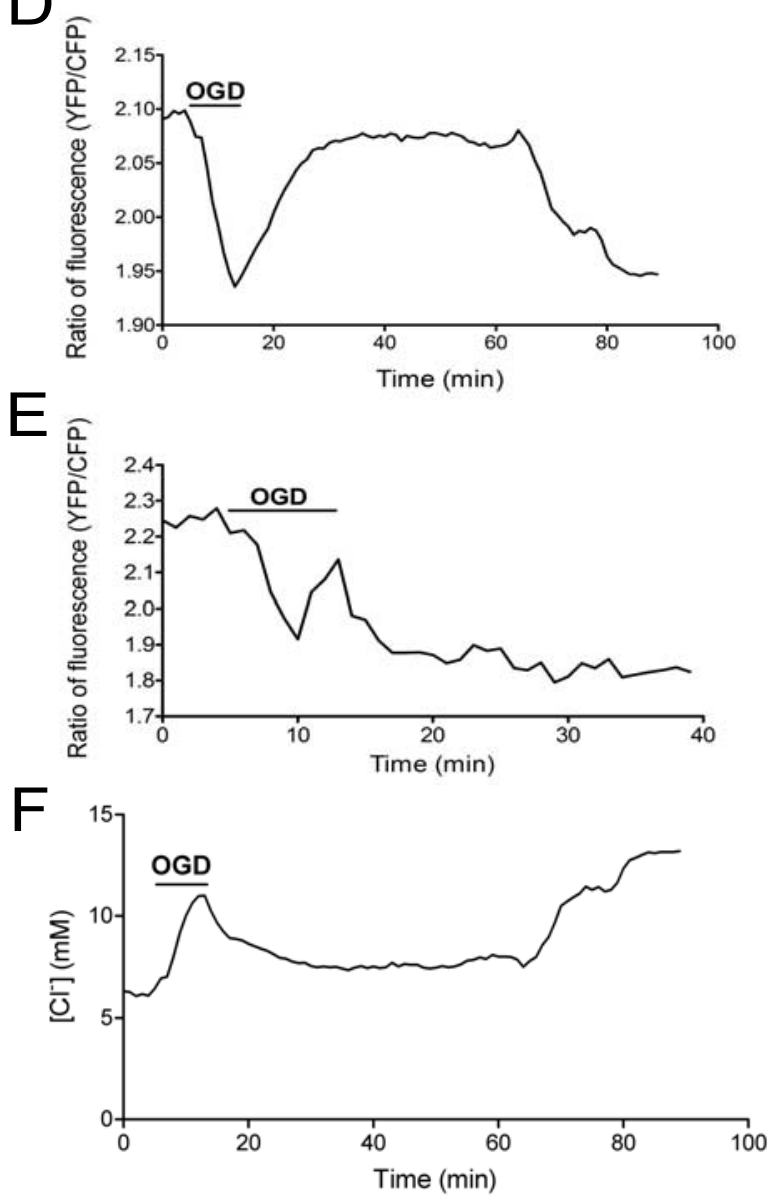

$3 A$. Specifically, we used the values shown by Kuner and Augustine (2000), their Figure 2D, to express the $\mathrm{pH}$ sensitivity of the apparent $K_{\mathrm{d}}\left(K_{\mathrm{d}}{ }^{\prime}\right)$ as $K_{\mathrm{d}}{ }^{\prime}=10^{((0.818 \times \mathrm{pH})-4.18)}$. Given that the OGD-induced $\mathrm{pH}$ changes could affect Clomeleon fluorescence, all measurements of $\left[\mathrm{Cl}^{-}\right]_{\mathrm{i}}$ during OGD reported in this paper are corrected for the changes in $\mathrm{pH}$ illustrated in Figure $4 B$.

\section{Effect of OGD on $\left[\mathrm{Cl}^{-}\right]_{\mathrm{i}}$}

To determine $\left[\mathrm{Cl}^{-}\right]_{\mathrm{i}}$ during and after OGD, we used acute hippocampal slices prepared from adult transgenic mice expressing Clomeleon in area CA1 pyramidal neurons. Clomeleon fluorescence emission, produced by exciting the CFP moiety of Clomeleon with $440 \mathrm{~nm}$ light, was monitored continually during an 8 min episode of OGD and the subsequent 75 min of reoxygenation. An image of Clomeleon fluorescence, obtained in area CA1 with a wide-field microscope, is shown in Figure 5A. Fluorescence was measured from individual pyramidal cell bodies, as indicated by the ovals in Figure $5 A$.

Oxygen-glucose deprivation caused a large and transient decrease in Clomeleon fluorescence emission at $530 \mathrm{~nm}$ (YFP) (Fig. $5 B$ ) and a smaller decrease in $485 \mathrm{~nm}$ emission (CFP) (Fig. 5C), resulting in a net decrease in the ratio of YFP/CFP emission (Fig. $5 D$ ). During reoxygenation, these changes in fluorescence emission recovered and were followed by a delayed decrease in YFP fluorescence, which resulted in a secondary reduction in the YFP/ CFP emission ratio (Fig. 5D). Although most of our experiments were performed at room temperature $\left(24^{\circ} \mathrm{C}\right)$, this biphasic change in the Clomeleon signal was also observed during OGD at $36^{\circ} \mathrm{C}$. At this higher temperature, the changes in Clomeleon ratios were larger and more rapid, probably resulting from greater $\mathrm{Cl}^{-}$and/or $\mathrm{pH}$ changes at the higher temperature (Fig. $5 E$ ).

The $\left[\mathrm{Cl}^{-}\right]_{\mathrm{i}}$ was calculated at $1 \mathrm{~min}$ intervals from the YFP/ CFP ratios recorded at room temperature (Fig. $5 F$ ), using Equation 1 and the calibration data depicted in Figure $3 A$. Resting $\left[\mathrm{Cl}^{-}\right]_{\mathrm{i}}$ in these neurons was $5.6 \pm 0.6 \mathrm{~mm}$, and OGD produced a $5.4 \pm 0.8 \mathrm{~mm}$ increase in $\left[\mathrm{Cl}^{-}\right]_{\mathrm{i}}$ (Fig. $\left.5 F\right)(p<0.05$ vs baseline $\left[\mathrm{Cl}^{-}\right]_{\mathrm{i}}$, ANOVA followed by Tukey's multiple comparison test; $n=33$ ). During reoxygenation, there was a transient and partial recovery of $\left[\mathrm{Cl}^{-}\right]_{\mathrm{i}}$ to resting levels, but $\left[\mathrm{Cl}^{-}\right]_{\mathrm{i}}$ starting rising again $45 \mathrm{~min}$ into reoxygenation and continued to increase throughout the recording period (Fig. $5 F$ ). The "bumpiness" in the secondary rise in $\left[\mathrm{Cl}^{-}\right]_{\mathrm{i}}$ is attributable to $\mathrm{Cl}^{-}$rising at different times in the measurements from individual cells that were combined to produce the average data shown in the figure. At 70 min after beginning reoxygenation, the rise in $\left[\mathrm{Cl}^{-}\right]_{\mathrm{i}}$ was $7.6 \pm$ $1.3 \mathrm{~mm}\left(p<0.05,\left[\mathrm{Cl}^{-}\right]_{\mathrm{i}}\right.$ vs baseline $\left[\mathrm{Cl}^{-}\right]_{\mathrm{i}}$, ANOVA followed by Tukey's multiple comparison test; $n=33$ ).

Several experiments reveal that the changes in Clomeleon flu-

$\leftarrow$

Figure 5. Imaging Clomeleon fluorescence changes in hippocampal slices subjected to OGD. $A$, Live image of hippocampal area $\mathrm{CA} 1$ neurons from an adult brain slice expressing Clomeleon; sample ROIs, which covered whole somal areas of individual pyramidal cells, are indicated. $\boldsymbol{B}$, OGD-induced changes in fluorescence of YFP moiety of Clomeleon expressed as percentage relative changes to the initial total fluorescence $\left(\Delta F / F_{0}\right)$. Images were captured every minute over a $90 \mathrm{~min}$ recording period. After a $5 \mathrm{~min}$ baseline recording period, slices were subjected to $8 \mathrm{~min}$ of $0 \mathrm{GD}$ and reoxygenated in the presence of glucose. Data are averages from three cells. C, Concomitant OGD-induced changes in fluorescence of CFP moiety of Clomeleon. D, OGDinduced changes in YFP/CFP emission ratios. Data are expressed as the average ratio value from 33 cells. $E, 0 G D$-induced changes in Clomeleon emission ratios from slices maintained at $36^{\circ} \mathrm{C}$. Data are expressed as the average from three cells. $\boldsymbol{F}, 0 \mathrm{GD}$-induced changes in $\left[\mathrm{Cl}^{-}\right]_{\mathrm{i}}$. YFP/CFP emission ratios presented in $\boldsymbol{D}$ were converted to $\left[\mathrm{Cl}^{-}\right]_{i}$ using Equation 1 and corrected for $\mathrm{pH}$ changes (see Materials and Methods). 


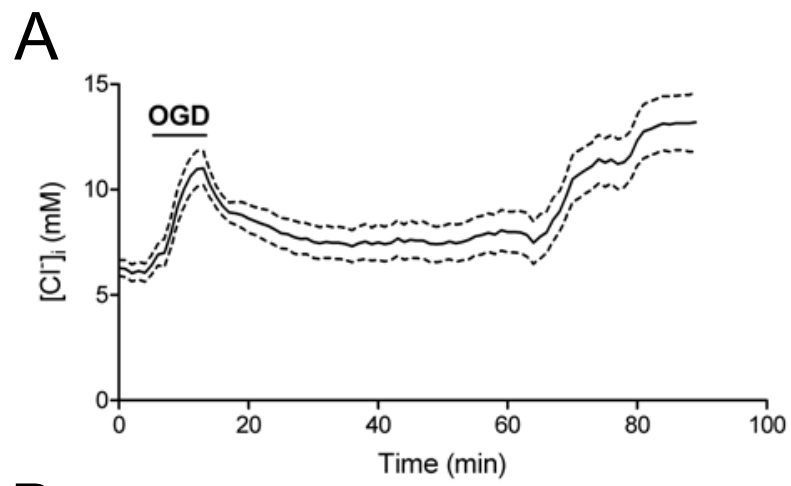

B

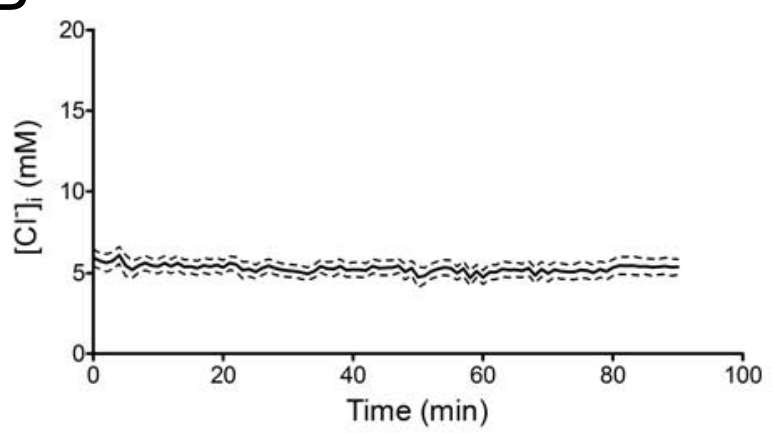

C

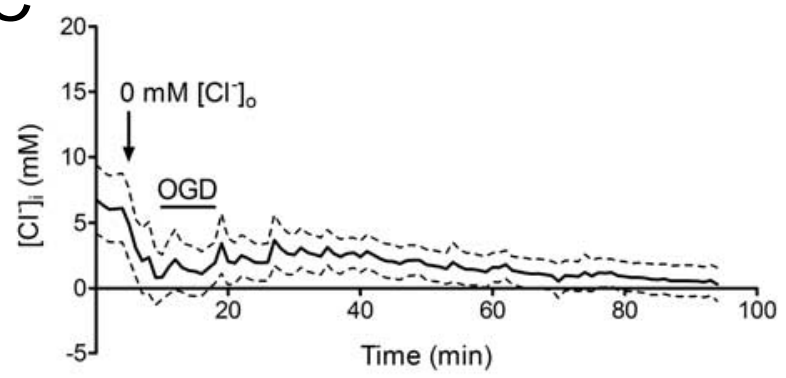

Figure 6. $\quad 0 G D$-induced changes in $\left[\mathrm{Cl}^{-}\right]_{\mathrm{i}}$ reported by Clomeleon. $\boldsymbol{A}$, Data from Figure $5 F$ are shown with the variability in the measurements. In this and the subsequent panels, SEs are represented as dashed lines. $\boldsymbol{B}$, Clomeleon fluorescence $\left(\left[\mathrm{Cl}^{-}\right]_{\mathrm{i}}\right)$ was measured in hippocampal slices not exposed to OGD. Data are expressed as the average from 15 cells. C, Chloride in the saline was replaced by gluconate before subjecting slices to $0 G D$ (indicated by arrow). Data are expressed as the average from three slices.

orescence represent genuine changes in $\left[\mathrm{Cl}^{-}\right]_{\mathrm{i}}$ in response to OGD. The biphasic rise in $\left[\mathrm{Cl}^{-}\right]_{\mathrm{i}}$ produced by OGD is shown in Figure $6 \mathrm{~A}$ along with the variability in the measurements. First, when slices were not exposed to OGD, there were no changes in $\left[\mathrm{Cl}^{-}\right]_{\mathrm{i}}$, indicating good maintenance of cellular $\mathrm{Cl}^{-}$homeostasis during the $2 \mathrm{~h}$ of recording under our conditions (Fig. $6 \mathrm{~B}$ ). The stable values for $\left[\mathrm{Cl}^{-}\right]_{\mathrm{i}}$ also indicate that there is no differential photobleaching of Clomeleon over $2 \mathrm{~h}$, which can affect determination of $\left[\mathrm{Cl}^{-}\right]_{\mathrm{i}}$ (Kuner and Augustine, 2000; Berglund et al., 2004). Second, to consider the contribution of autofluorescence, we measured fluorescence in slices from wild-type mice during OGD. The contribution of autofluorescence was $<1 \%$ of the Clomeleon emission signal; OGD decreased the autofluorescence signals to the same extent at both emission wavelengths, unlike OGD-induced changes in Clomeleon fluorescence (data not shown). Furthermore, there was no recovery of the change in autofluorescence during reoxygenation. Because of these differences in the responses of autofluorescence signals to OGD, we conclude that changes in autofluorescence do not contaminate
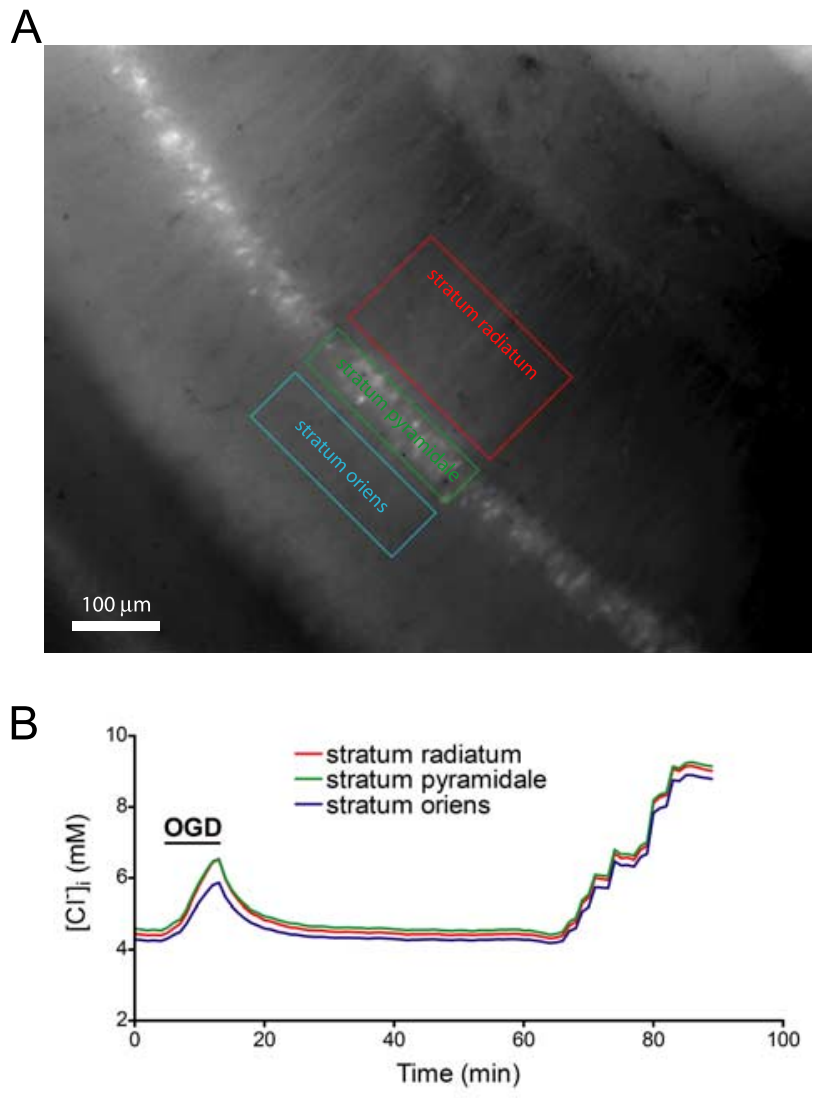

Figure 7. Imaging Clomeleon fluorescence changes in regions within hippocampal slices subjected to 0GD. A, Low-magnification image of area CA1 of the hippocampus. A part of the area was viewed by a high-magnification objective lens to image the cell body layer and two dendritic fields as indicated by boxes. $B, 0 G D$-induced changes in $\left[\mathrm{Cl}^{-}\right]_{i}$ within areas labeled in $A$. Data are expressed as the average $\left[\mathrm{Cl}^{-}\right]_{\mathrm{i}}$ value from three slices. The $\mathrm{SEs}$ have been removed for clarity and ranged between 0.14 and $0.15 \mathrm{~mm}$. Note that the range of SEs (in millimolar) will be indicated for all subsequent figures of recordings and are similar to the ranges shown in Figure $6 \mathrm{~A}$.

Clomeleon responses significantly during OGD. Third, to evaluate the contribution of $\mathrm{Cl}^{-}$to the Clomeleon response, OGD was induced in slices superfused with a $\mathrm{Cl}^{-}$-free saline. Removing external $\mathrm{Cl}^{-}$produced the expected reduction in resting $\left[\mathrm{Cl}^{-}\right]_{\mathrm{i}}$. Furthermore, OGD did not induce any significant rises in $\left[\mathrm{Cl}^{-}\right]_{\mathrm{i}}$ when external $\mathrm{Cl}^{-}$was absent (Fig. 6C), suggesting that the OGDinduced changes in Clomeleon signals were attributable specifically to an influx of $\mathrm{Cl}^{-}$or decreased efflux of $\mathrm{Cl}^{-}$in area CA1 cells.

To determine whether there were any regional differences in the response of CA1 cells to OGD, we examined Clomeleon responses in the different layers of the CA1. Because Clomeleon is expressed only in these cells, we could determine $\left[\mathrm{Cl}^{-}\right]_{\mathrm{i}}$ by integrating Clomeleon fluorescence within areas containing the basilar dendrites, apical dendrites, or cell bodies of the pyramidal cells The extent to which OGD increased intracellular $\mathrm{Cl}^{-}$in the pyramidal cell bodies was the same as that measured in the basilar and apical dendrites within strata oriens and radiatum, respectively (Fig. 7). Thus, at this level of resolution, there were no detectable spatial gradients of $\left[\mathrm{Cl}^{-}\right]_{\mathrm{i}}$ induced by OGD.

\section{$\left[\mathrm{Cl}^{-}\right]_{\mathrm{i}}$ increases and neuronal damage}

Because increases in $\left[\mathrm{Cl}^{-}\right]_{\mathrm{i}}$ are reported to cause excitotoxic cell death (Rothman, 1985; Choi and Rothman, 1990; Beck et al., 2003), it is possible that the increases in $\left[\mathrm{Cl}^{-}\right]_{\mathrm{i}}$ produced by OGD may contribute directly to neuronal damage. We tested this pos- 

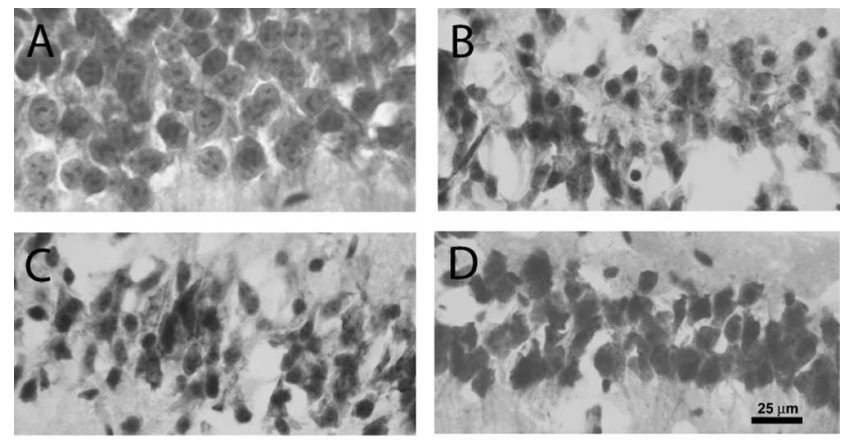

E

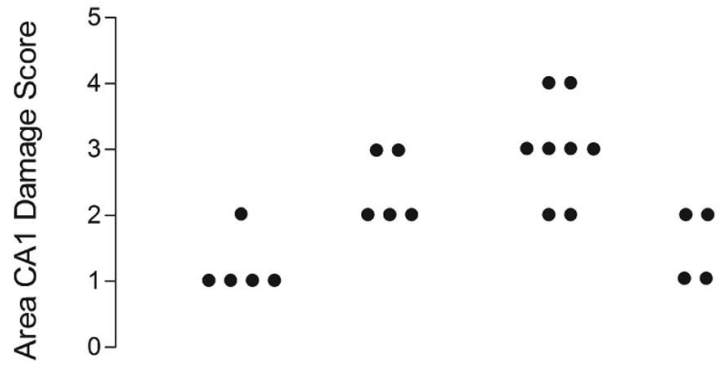

$6 \mathrm{mM} \mathrm{Cl}^{-} 12 \mathrm{mM} \mathrm{Cl}^{-}$

OGD

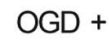

low $\mathrm{Cl}^{-}$

Figure 8. Effect of chloride on neuronal damage in hippocampal area CA1. Neurons in hippocampal area $\mathrm{CA} 1$ were "clamped" with baseline concentrations of $\mathrm{Cl}^{-}(6 \mathrm{~mm})(\boldsymbol{A})$ or elevated $\mathrm{Cl}^{-}$concentrations (12 mm) (B) for $2.25 \mathrm{~h}$. Other hippocampal slices were subjected to OGD in the presence of normal physiologic saline $(\boldsymbol{C})$ or in a low $\mathrm{Cl}^{-}$-containing saline $(\boldsymbol{D})$ and reoxygenated for $3 \mathrm{~h}$. E, Damage scores were determined according to the rating scale described in Materials and Methods. Each point represents scores from a single hippocampal slice obtained from several experiments in at least three mice. Damage scores for $12 \mathrm{~mm} \mathrm{Cl}^{-}$were significantly different than $6 \mathrm{~mm} \mathrm{Cl}^{-}(p<0.05$, Kruskal-Wallis test for damage score followed by MannWhitney U post hoc analysis; $n=5)$. The effect of a low $\mathrm{Cl}^{-}$saline during reoxygenation was significantly different than that of the normal physiologic saline during reoxygenation after OGD ( $p<0.05$, Kruskal-Wallis test for damage score followed by Mann-Whitney $U$ post hoc analysis; $n=4-8)$.

sibility by examining neuronal survival after manipulating $\left[\mathrm{Cl}^{-}\right]_{\mathrm{i}}$. First, we asked whether directly elevating $\left[\mathrm{Cl}^{-}\right]_{\mathrm{i}}$ without producing OGD could cause neuronal damage. The measurements shown in Figure $5 \mathrm{~F}$ indicate that $\left[\mathrm{Cl}^{-}\right]_{\mathrm{i}}$ reaches levels during reoxygenation that are twice as high as basal $\left[\mathrm{Cl}^{-}\right]_{\mathrm{i}}, \sim 12 \mathrm{mM}$ compared with $6 \mathrm{~mm}$ before OGD. To clamp $\left[\mathrm{Cl}^{-}\right]_{\mathrm{i}}$ at each of these two levels, we treated slices with tributyltin and nigericin (as done in the calibration experiments shown in Fig. $3 A$ ) to equilibrate intracellular and extracellular $\left[\mathrm{Cl}^{-}\right]$, while maintaining extracellular $\left[\mathrm{Cl}^{-}\right]$at either 12 or $6 \mathrm{~mm}$ for $2.25 \mathrm{~h}$. Using a scoring procedure to assess the degree of neuronal damage in area CA1 (Pond et al., 2004), we found that raising $\left[\mathrm{Cl}^{-}\right]_{\mathrm{i}}$ to $12 \mathrm{~mm}$ induced mild neuronal damage in CA1 pyramidal neurons, similar to what was observed after OGD (Fig. 8). In contrast, maintaining $\left[\mathrm{Cl}^{-}\right]_{\mathrm{i}}$ at $6 \mathrm{~mm}$ produced less neuronal damage $(p<0.05,12$ vs 6 $\mathrm{mm} \mathrm{Cl}^{-}$, Mann-Whitney $U$ test), comparable with what was observed when extracellular $\left[\mathrm{Cl}^{-}\right]$was kept low during OGD (see below). Because tributyltin and nigericin were included in both the control condition $\left(6 \mathrm{~mm}\left[\mathrm{Cl}^{-}\right]_{\mathrm{i}}\right)$ and the elevated $\left[\mathrm{Cl}^{-}\right]_{\mathrm{i}}$ condition $\left(12 \mathrm{~mm}\left[\mathrm{Cl}^{-}\right]_{\mathrm{i}}\right)$, it is unlikely that the damage was attributable to these agents themselves but instead was attributable to elevated $\left[\mathrm{Cl}^{-}\right]_{\mathrm{i}}$. Based on these findings, we conclude that a rise in $\left[\mathrm{Cl}^{-}\right]_{\mathrm{i}}$ is sufficient to cause mild neuronal damage.

To complement this set of experiments, we also asked whether

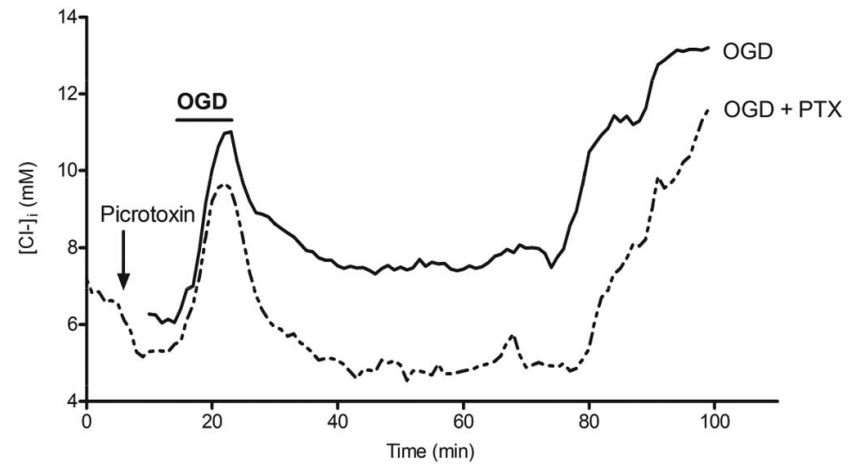

Figure 9. The effect of preincubation with the $\mathrm{GABA}$-gated $\mathrm{Cl}^{-}$channel blocker picrotoxin (PTX; $100 \mu \mathrm{M}$ ) on OGD-induced $\left[\mathrm{Cl}^{-}\right]_{\mathrm{i}}$ increases during and after OGD. Slices were exposed to 8 min of OGD and 75 min of reoxygenation in the presence (dotted line) or absence (solid line) of picrotoxin. The arrow represents the time when picrotoxin was added to the superfusion saline. Picrotoxin was present for the remainder of the recording period. Data are expressed as the average $\left[\mathrm{Cl}^{-}\right]_{i}$ value from 33 and 49 cells, in the absence or presence of picrotoxin, respectively. SEs have been removed for clarity and ranged between 0.53 and $1.4 \mathrm{~mm}$.

the OGD-induced rises in $\left[\mathrm{Cl}^{-}\right]_{\mathrm{i}}$ are necessary for neuronal damage. This was done by exposing slices to OGD and allowing them to recover in a superfusion saline containing a low concentration of $\mathrm{Cl}^{-}(10 \mathrm{~mm})$, a procedure that completely prevents the secondary rise in intracellular $\mathrm{Cl}^{-}$that occurs $2 \mathrm{~h}$ after OGD (Galeffi et al., 2004). Slices were harvested $3 \mathrm{~h}$ after reoxygenation and scored for neuronal damage in area CA1. When the slices were reoxygenated in the low $\left[\mathrm{Cl}^{-}\right]$saline, there was a significant attenuation of damage to CA1 pyramidal neurons compared with slices reoxygenated in regular saline $(p<0.05$ OGD vs OGD-low $\mathrm{Cl}^{-}$, Mann-Whitney $U$ test) (Fig. 8). These results support the idea that an increase in neuronal $\left[\mathrm{Cl}^{-}\right]_{\mathrm{i}}$ is necessary to produce neuronal damage after OGD.

Together, the results of the two different experiments indicate that the OGD-induced rise in $\left[\mathrm{Cl}^{-}\right]_{\mathrm{i}}$ is both sufficient and necessary to produce neuronal damage. Thus, the $\left[\mathrm{Cl}^{-}\right]_{\mathrm{i}}$ changes are not simply a consequence of neuronal damage but instead are causally responsible for this damage.

\section{OGD-induced changes in $\left[\mathrm{Cl}^{-}\right]_{\mathrm{i}}$ : effect of $\mathrm{Cl}^{-}$transport inhibitors}

To determine the sources of $\mathrm{Cl}^{-}$responsible for the increases in $\left[\mathrm{Cl}^{-}\right]_{\mathrm{i}}$ associated with OGD, we investigated the ability of various $\mathrm{Cl}^{-}$channel and transport inhibitors to prevent OGD-induced $\left[\mathrm{Cl}^{-}\right]_{\mathrm{i}}$ rises. It has been proposed previously that activation of $\mathrm{GABA}_{\mathrm{A}}$ receptors may contribute to an influx of $\mathrm{Cl}^{-}$in neurons during OGD (Inglefield and Schwartz-Bloom, 1998; Allen et al., 2004). To investigate the role of the $\mathrm{GABA}_{\mathrm{A}}$-gated $\mathrm{Cl}^{-}$channel in OGD-induced changes in $\left[\mathrm{Cl}^{-}\right]_{\mathrm{i}}$, slices were preincubated with picrotoxin, a blocker of $\mathrm{GABA}_{\mathrm{A}}$ receptor $\mathrm{Cl}^{-}$channels. Picrotoxin caused a slight but significant decrease in baseline $\left[\mathrm{Cl}^{-}\right]_{\mathrm{i}}$ in the slices (Fig. 9) $(p<0.05$, repeated-measures ANOVA; $n=$ 49), presumably attributable to block of tonic inhibition by GABA (Allen et al., 2004). Picrotoxin did not significantly alter the initial rise in $\left[\mathrm{Cl}^{-}\right]_{\mathrm{i}}$ occurring during OGD, but it did hasten recovery of $\left[\mathrm{Cl}^{-}\right]_{\mathrm{i}}$ to resting levels after OGD (Fig. 9) $(p<0.05$, repeated-measures ANOVA; $n=33-49$ ). Additionally, picrotoxin was unable to prevent the secondary increase in $\left[\mathrm{Cl}^{-}\right]_{\mathrm{i}}$ during reoxygenation, although it did delay the onset of this response (Fig. 9). At $75 \mathrm{~min}$ of reoxygenation, the $\left[\mathrm{Cl}^{-}\right]_{\mathrm{i}}$ was $11.6 \pm 0.5$ and $13.2 \pm 1.3 \mathrm{~mm}$ in the presence and absence of picrotoxin, respectively $(p>0.05$, NS, ANOVA followed by 

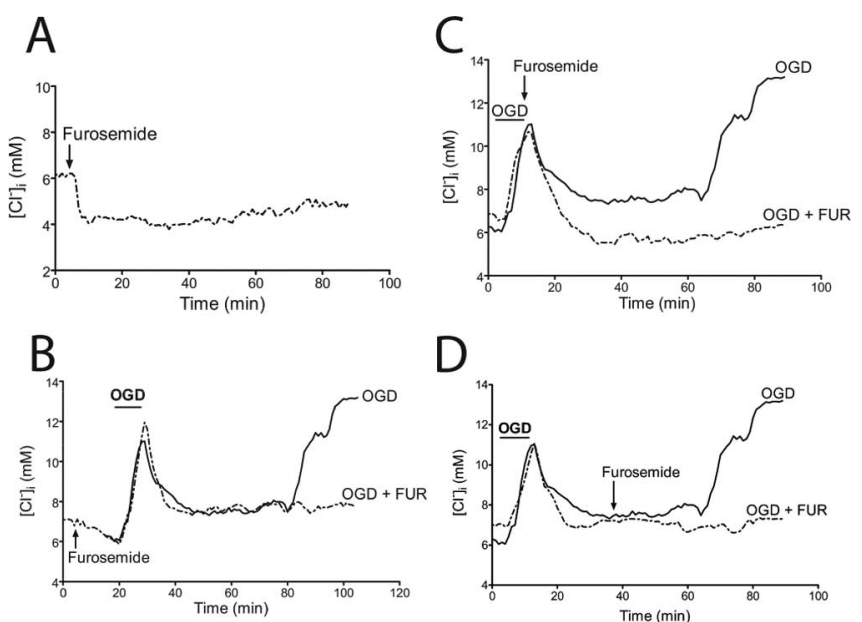

Figure 10. The effect of the $\mathrm{Cl}^{-}$transport inhibitor furosemide (300 $\left.\mu \mathrm{m}\right)$ on OGD-induced $\mathrm{Cl}^{-}$changes. Slices were exposed to 8 min of $O G D$ and 75 min of reoxygenation in the presence (dashed lines) or absence (solid lines) of furosemide (FUR). The arrows in $\boldsymbol{B}-\boldsymbol{D}$ represent the time when furosemide was added to the superfusion saline; it was present for the remainder of the recording period. $\boldsymbol{A}$, Imaging Clomeleon in slices exposed to furosemide (300 $\mu \mathrm{m})$ in the absence of $0 G D$. After a 5 min baseline recording period, furosemide was added to the superfusion saline for $90 \mathrm{~min}$. Furosemide data are expressed as the average $\left[\mathrm{Cl}^{-}\right]_{\mathrm{i}}$ value from 17 cells. SEs for furosemide-exposed slices ranged between 0.53 and $0.68 \mathrm{~mm}$. $\boldsymbol{B}$, The effect of adding furosemide before $0 \mathrm{GD}$ on increases in $\left[\mathrm{Cl}^{-}\right]_{\mathrm{i}}$ during and after $\mathrm{OGD}$. Furosemide data are expressed as the average $\left[\mathrm{Cl}^{-}\right]_{i}$ value from 16 cells. SEs for furosemide-exposed slices ranged between 0.80 and $1.8 \mathrm{~mm}$. $\boldsymbol{C}$, The effect of adding furosemide after OGD on the elevations in $\left[\mathrm{Cl}^{-}\right]_{i}$ associated with $0 G D$. Furosemide data are expressed as the average $\left[\mathrm{Cl}^{-}\right]_{\mathrm{i}}$ value from 16 cells. SEs for furosemide-exposed slices ranged between 0.37 and $1.2 \mathrm{~mm}$. $\boldsymbol{D}$, The effect of delaying furosemide addition to 30 min into reoxygenation on $\left[\mathrm{Cl}^{-}\right]_{\mathrm{i}}$ accumulation after $0 \mathrm{GD}$. Furosemide data are expressed as the average $\left[\mathrm{Cl}^{-}\right]_{i}$ value from 15 cells. SEs for furosemideexposed slices ranged between 0.81 and $1.5 \mathrm{~mm}$.

Tukey's multiple comparison test). Therefore, it appears that $\mathrm{GABA}_{\mathrm{A}}$ receptors do not contribute significantly to the secondary increase in $\left[\mathrm{Cl}^{-}\right]_{\mathrm{i}}$.

Because NKCC inhibitors are neuroprotective after OGD (Beck et al., 2003; Pond et al., 2004), we hypothesized that these inhibitors may prevent the rises in $\left[\mathrm{Cl}^{-}\right]_{\mathrm{i}}$ resulting from OGD. Therefore, we determined the effect of furosemide $(300 \mu \mathrm{M})$ on $\left[\mathrm{Cl}^{-}\right]_{\mathrm{i}}$ levels. At this concentration, furosemide inhibits both $\mathrm{Cl}^{-}$ influx through NKCC and $\mathrm{Cl}^{-}$efflux through the $\mathrm{K}^{+}{ }_{-} \mathrm{Cl}^{-}$cotransporter (KCC) (Payne et al., 2003). Furosemide produced a slight decrease in $\left[\mathrm{Cl}^{-}\right]_{\mathrm{i}}$ in slices not subjected to OGD (Fig. 10A) $\left(p<0.05\right.$ vs baseline $\left[\mathrm{Cl}^{-}\right]_{\mathrm{i}}$, ANOVA followed by Tukey's multiple comparison test; $n=17$ ). Most dramatically, furosemide completely prevented the secondary rise in $\left[\mathrm{Cl}^{-}\right]_{\mathrm{i}}$ normally observed during reoxygenation, limiting $\left[\mathrm{Cl}^{-}\right]_{\mathrm{i}}$ to $7.7 \pm 1.2 \mathrm{mM}$ at 75 min of reoxygenation (Fig. $10 B)(p<0.05$ vs the absence of furosemide, ANOVA followed by Tukey's multiple comparison test; $n=16-33$ ). To determine whether incubation with furosemide throughout OGD was necessary to prevent the secondary rise in $\left[\mathrm{Cl}^{-}\right]_{\mathrm{i}}$, we examined the effect of delaying furosemide treatment until after OGD. We found that post-OGD addition of furosemide (Fig. 10C) yielded results very similar to those observed when furosemide was continually present (Fig. $10 \mathrm{~B}$ ), limiting $\left[\mathrm{Cl}^{-}\right]_{\mathrm{i}}$ to $6.3 \pm 0.8 \mathrm{~mm}$ at $75 \mathrm{~min}$ of reoxygenation $(p<0.05$ vs the absence of furosemide, ANOVA followed by Tukey's multiple comparison test; $n=16-33$ ). Because furosemide promotes recovery of $\left[\mathrm{Cl}^{-}\right]_{\mathrm{i}}$ to baseline levels after OGD, this could protect neurons from damage during reoxygenation and thereby prevent the secondary rises in $\left[\mathrm{Cl}^{-}\right]_{\mathrm{i}}$ from occurring. To investigate whether NKCC and/or KCC is involved directly in the secondary
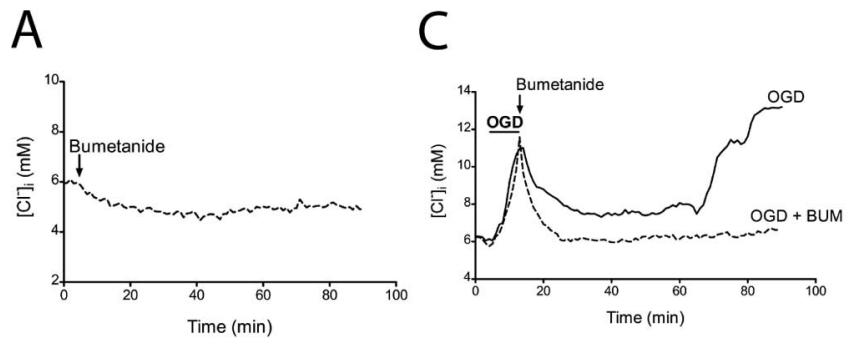

B

$\mathrm{D}$
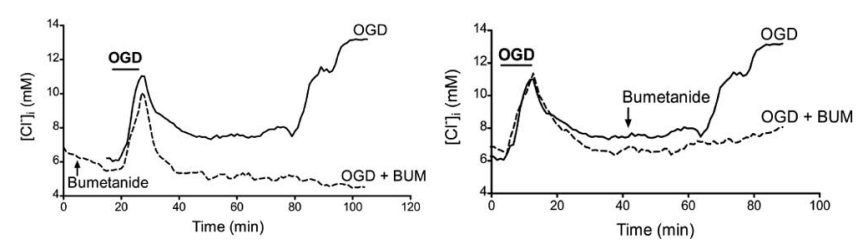

Figure 11. The effect of the $\mathrm{Cl}^{-}$transport inhibitor bumetanide $(10 \mu \mathrm{m})$ on $0 \mathrm{GD}$-induced $\left[\mathrm{Cl}^{-}\right]_{\mathrm{i}}$ changes. Slices were exposed to $8 \mathrm{~min}$ of $\mathrm{OGD}$ and $75 \mathrm{~min}$ of reoxygenation in the presence (dashed lines) or absence (solid lines) of bumetanide. The arrows in $\boldsymbol{B}-\boldsymbol{D}$ represent the time when the bumetanide (BUM) was added to the superfusion medium. $\boldsymbol{A}$, Imaging Clomeleon in slices exposed to bumetanide $(10 \mu \mathrm{m})$ in the absence of OGD. After a 5 min baseline recording period, bumetanide was added to the superfusion saline for $90 \mathrm{~min}$. Bumetanide data are expressed as the average $\left[\mathrm{Cl}^{-}\right]_{\mathrm{i}}$ value from 15 cells. SEs in bumetanide-exposed slices ranged between 0.39 and $0.89 \mathrm{~mm}$. $\boldsymbol{B}$, The effect of adding bumetanide before $0 G \mathrm{G}$ on OGDinduced increases in $\left[\mathrm{Cl}^{-}\right]_{\mathrm{i}}$. Bumetanide data are expressed as the average $\left[\mathrm{Cl}^{-}\right]_{\mathrm{i}}$ value from 16 cells. SEs for bumetanide-exposed slices ranged between 0.68 and $1.0 \mathrm{~mm}$. C, The effect adding bumetanide after $0 \mathrm{GD}$ on $\left[\mathrm{Cl}^{-}\right]_{\mathrm{i}}$ elevations after $\mathrm{OGD}$. Bumetanide data are expressed as the average $\left[\mathrm{Cl}^{-}\right]_{\mathrm{i}}$ value from 16 cells. SEs for bumetanide-exposed slices ranged between 0.72 and $0.78 \mathrm{~mm}$. $\boldsymbol{D}$, The effect of delayed bumetanide addition (to 30 min into reoxygenation) on the increase in $\left[\mathrm{Cl}^{-}\right]_{\mathrm{i}}$ during reoxygenation. Bumetanide data are expressed as the average $\left[\mathrm{Cl}^{-}\right]_{\mathrm{i}}$ value from 17 cells. SEs in bumetanide-exposed slices ranged between 0.49 and $1.2 \mathrm{~mm}$.

rise in $\left[\mathrm{Cl}^{-}\right]_{\mathrm{i}}$, furosemide addition was delayed until $30 \mathrm{~min}$ after the onset of reoxygenation. In this case, furosemide significantly reduced the secondary rise in $\left[\mathrm{Cl}^{-}\right]_{\mathrm{i}}$ (Fig. 10D). At $75 \mathrm{~min}$ of reoxygenation, $\left[\mathrm{Cl}^{-}\right]_{\mathrm{i}}$ in these slices was $6.5 \pm 0.8 \mathrm{mM}$ compared with $13.2 \pm 1.3 \mathrm{~mm}$ in slices not exposed to furosemide $(p<$ 0.05 , ANOVA followed by Tukey's multiple comparison test; $n=$ 15-33). Thus, block of the secondary rise in $\left[\mathrm{Cl}^{-}\right]_{\mathrm{i}}$ only requires that furosemide be present during the time when the secondary rise would occur, indicating that furosemide-sensitive $\mathrm{Cl}^{-}$transport mechanisms (NKCC and/or KCC) are responsible for this $\left[\mathrm{Cl}^{-}\right]_{\mathrm{i}}$ increase.

To specifically examine the role of NKCC-1 in the $\left[\mathrm{Cl}^{-}\right]_{\mathrm{i}}$ increases, we superfused slices with bumetanide $(10 \mu \mathrm{M})$. Bumetanide at this concentration should inhibit $\mathrm{Cl}^{-}$influx selectively through NKCC-1 (Payne et al., 2003), the sole subtype of NKCC found in the brain (Russell, 2000). The presence of bumetanide alone did not significantly decrease baseline $\left[\mathrm{Cl}^{-}\right]_{\mathrm{i}}$ (Fig. $11 \mathrm{~A}$ ) $(p>0.05$, NS, ANOVA; $n=15)$. Addition of bumetanide had only a small effect on the rise in $\left[\mathrm{Cl}^{-}\right]_{\mathrm{i}}$ during $\mathrm{OGD}$, but it did enhance recovery of $\left[\mathrm{Cl}^{-}\right]_{\mathrm{i}}$ after OGD (Fig. $11 \mathrm{~B}$ ). Like furosemide, bumetanide also prevented $\left[\mathrm{Cl}^{-}\right]_{\mathrm{i}}$ from increasing during reoxygenation (Fig. $11 B, C$ ). Preincubation with bumetanide and incubation with bumetanide after OGD maintained $\left[\mathrm{Cl}^{-}\right]_{\mathrm{i}}$ measured $75 \mathrm{~min}$ into reoxygenation at $4.5 \pm 0.3$ and $6.6 \pm 0.4$ $\mathrm{mM}$, respectively (Fig. $11 \mathrm{~A}, B)\left(p<0.05 \mathrm{vs}\left[\mathrm{Cl}^{-}\right]_{\mathrm{i}}\right.$ after OGD in the absence of bumetanide, ANOVA followed by Tukey's multiple comparison test; $n=16-33$ ). In some experiments, bumetanide addition was delayed until $30 \mathrm{~min}$ of reoxygenation, but this drug still eliminated the secondary rise in $\left[\mathrm{Cl}^{-}\right]_{\mathrm{i}}$ when applied at this time (Fig. $11 D$ ). The $\left[\mathrm{Cl}^{-}\right]_{\mathrm{i}}$ at $75 \mathrm{~min}$ into reoxygen- 
ation was $7.7 \pm 0.8$ versus $13.2 \pm 1.3 \mathrm{~mm}$ in slices not exposed to bumetanide (Fig. 11D) $(p<0.05$, ANOVA followed by Tukey's multiple comparison test; $n=17-$ 33). This indicates that the secondary rise in $\left[\mathrm{Cl}^{-}\right]_{\mathrm{i}}$ is attributable primarily to influx of $\mathrm{Cl}^{-}$via NKCC-1.

Because intracellular $\mathrm{pH}$ and $\mathrm{Cl}^{-}$levels are coupled via the $\mathrm{Cl}^{-} / \mathrm{HCO}_{3}{ }^{-}$exchanger (Schlue and Deitmer, 1988), we also determined whether $\mathrm{Cl}^{-}$transport inhibitors such as bumetanide might affect the intracellular $\mathrm{pH}$, influencing the $\mathrm{Cl}^{-}$measurements reported by Clomeleon. Bumetanide did not affect intracellular $\mathrm{pH}$ before OGD; the intracellular $\mathrm{pH}$ was $7.12 \pm 0.03$ versus $7.10 \pm 0.03$ in the absence and presence of bumetanide, respectively ( $p>0.05$, NS, ANOVA; $n=24-26$ ). Additionally, bumetanide had no effect on the transient decrease in intracellular $\mathrm{pH}$ produced by OGD $(\Delta \mathrm{pH}=0.14 \pm 0.04$ vs $0.18 \pm 0.03$ for vehicle and bumetanide, respectively; $p>0.05$, NS, ANOVA; $n=$ 24-26), nor on intracellular $\mathrm{pH}$ during reoxygenation. Although not tested here, it is unlikely that the $\mathrm{GABA}_{\mathrm{A}}$ receptor blocker picrotoxin would affect intracellular $\mathrm{pH}$ because intracellular $\mathrm{pH}$ does not change with the GABA-mediated influx of $\mathrm{Cl}^{-}$, as reported by Clomeleon (Kuner and Augustine, 2000).

\section{Effect of OGD on NKCC-1 activity}

The actions of furosemide and bumetanide (Figs. 10, 11) indicate that NKCC-1 is involved in OGD-induced $\mathrm{Cl}^{-}$increases after OGD. We next asked whether this enhancement of $\left[\mathrm{Cl}^{-}\right]_{\mathrm{i}}$ via NKCC-1 during OGD is attributable to an increase in the level of expression of NKCC-1. Levels of NKCC-1 were assessed by Western blotting, using an antibody that recognizes NKCC- 1 in the brain; an antibody specific for $\beta$ III tubulin was used as a loading control. Oxygen-glucose deprivation did not significantly change the amount of NKCC-1 expressed in hippocampal slices up to $2 \mathrm{~h}$ after OGD (Fig. 12A,B). Thus, it is unlikely that the secondary rise in $\left[\mathrm{Cl}^{-}\right]_{\mathrm{i}}$ is attributable to increased expression of NKCC-1. We next considered whether the increased influx of $\mathrm{Cl}^{-}$is attributable to an increase in the activity of NKCC-1. To examine this possibility, we measured the degree of phosphorylation of NKCC-1, which is known to be correlated with the level of NKCC-1 activity (Darman and Forbush, 2002). This was done by using a polyclonal antibody with an epitope that is a diphosphopeptide containing T184 and T189 of NKCC-1 (Flemmer et al., 2002). Oxygen-glucose deprivation substantially increased the amount of pNKCC- 1 at 1 and $2 \mathrm{~h}$ after OGD (Fig. 12 A). There was a significant increase in the ratio of $\mathrm{pNKCC}-1$ relative to total NKCC-1 protein after OGD, indicating that NKCC-1 phosphorylation does indeed increase during the time that $\left[\mathrm{Cl}^{-}\right]_{\mathrm{i}}$ rises after reoxygenation (Fig. 12C).

\section{Discussion}

We used Clomeleon, a genetically encoded ratiometric indicator, to measure $\left[\mathrm{Cl}^{-}\right]_{\mathrm{i}}$ changes in mouse hippocampal neurons during OGD and reoxygenation. With this approach, we quantified the biphasic increase in $\left[\mathrm{Cl}^{-}\right]_{\mathrm{i}}$. produced by OGD. Treatment with transport inhibitors revealed that activation of NKCC-1 underlies this rise in $\left[\mathrm{Cl}^{-}\right]_{\mathrm{i}}$. Finally, manipulation of $\left[\mathrm{Cl}^{-}\right]_{\mathrm{i}}$ indicated that these OGD-induced disruptions in $\mathrm{Cl}^{-}$homeostasis are involved in the neuronal damage that occurs after tissues are deprived of oxygen and glucose.

\section{Measuring $\left[\mathrm{Cl}^{-}\right]_{\mathrm{i}}$ with Clomeleon}

Clomeleon offers several advantages over other methods that have been used to measure $\left[\mathrm{Cl}^{-}\right]_{\mathrm{i}}$ during OGD. Electrophysiological estimates of $\left[\mathrm{Cl}^{-}\right]_{\mathrm{i}}$ may be confounded by the inactivation of GABA receptors after OGD (Allen et al., 2004). Furthermore, Clomeleon enables measurement of $\left[\mathrm{Cl}^{-}\right]_{\mathrm{i}}$ over extended periods of time after OGD, which is not easily achieved with electrophysiological recordings or with organic dyes that can leak out of cells over time. Unlike most organic optical $\mathrm{Cl}^{-}$indicators, such as 6-methoxy- $N$ ethylquinolinium chloride (MEQ), Clomeleon is a ratiometric indicator that can provide $\left[\mathrm{Cl}^{-}\right]_{\mathrm{i}}$ measurements that are independent of OGD-induced cell swelling and shrinkage, which alter indicator concentration and optical path length. Finally, Clomeleon absorbs and emits light at visible wavelengths, allowing Clomeleon to be used in conjunction with the $\mathrm{Cl}^{-}$transport inhibitors bumetanide and furosemide, which absorb UV light and quench MEQ (Fukuda et al., 1998). This advantage allowed us to define the role of $\mathrm{Cl}^{-}$transporters in the increase in $\left[\mathrm{Cl}^{-}\right]_{\mathrm{i}}$ produced after OGD.

\section{Oxygen-glucose deprivation-induced $\left[\mathrm{Cl}^{-}\right]_{\mathrm{i}}$ changes: role of $\mathrm{Cl}^{-}$transporters}

Oxygen-glucose deprivation produced two temporally distinct phases of increased $\left[\mathrm{Cl}^{-}\right]_{\mathrm{i}}$. During OGD, $\left[\mathrm{Cl}^{-}\right]_{\mathrm{i}}$ approximately doubled and then rapidly recovered when oxygen and glucose were restored. After $\sim 1$ h of reoxygenation, there was a secondary rise in $\left[\mathrm{Cl}^{-}\right]_{\mathrm{i}}$ that reached levels higher than those measured during OGD and persisted for the duration of the measurements. These results are in qualitative agreement with a previous study in which the $\mathrm{Cl}^{-}$ indicator MEQ was used to determine relative changes in $\left[\mathrm{Cl}^{-}\right]_{\mathrm{i}}$ in adult rat hippocampal slices subjected to OGD (Galeffi et al., 2004). We extended the previous observations by using hippocampal slices from adult Clomeleon transgenic mice to provide continuous determinations of $\left[\mathrm{Cl}^{-}\right]_{\mathrm{i}}$ and to examine the effects of the NKCC and KCC inhibitors bumetanide and furosemide.

We found that bumetanide and furosemide, as well as the $\mathrm{GABA}_{\mathrm{A}}$ receptor blocker picrotoxin, were incapable of reducing the initial rise in $\left[\mathrm{Cl}^{-}\right]_{\mathrm{i}}$ during OGD. Similarly, in cultured hippocampal neurons exposed to glutamate, bumetanide and furosemide do not prevent glutamate from elevating $\left[\mathrm{Cl}^{-}\right]_{\mathrm{i}}$, and the $\mathrm{GABA}_{\mathrm{A}}$ antagonist bicuculline only slightly reduces the rise in $\left[\mathrm{Cl}^{-}\right]_{\mathrm{i}}$ (Slemmer et al., 2004). These results indicate that NKCC, $\mathrm{KCC}$, and $\mathrm{GABA}_{\mathrm{A}}$ receptors are not (solely) responsible for this 
rise in $\left[\mathrm{Cl}^{-}\right]_{\mathrm{i}}$. It is likely that OGD activates many pathways for $\mathrm{Cl}^{-}$entry. During OGD, there is massive depolarization of the membrane potential $\left(V_{\mathrm{m}}\right)$; this is attributable to many ion channels opening, because the depolarization is prevented only by the presence of multiple ion channel blockers (Sömjen, 2001). The almost complete reduction in intracellular ATP at the end of OGD (Galeffi et al., 2000) and consequent collapse of the $\mathrm{Na}^{+} / \mathrm{K}^{+}$gradient also contribute to breakdown of the $V_{\mathrm{m}}$. At physiological temperature, this OGD-induced depolarization can approach $0 \mathrm{mV}$ in hippocampal pyramidal neurons (Hansen, 1985; Tanaka et al., 1997). This depolarization would enhance an inwardly directed electrochemical gradient for $\mathrm{Cl}^{-}$. Our measurements indicate that $\left[\mathrm{Cl}^{-}\right]_{\mathrm{i}}$ reaches $\sim 11 \mathrm{mM}$ during OGD treatment (Fig. $5 F)$, corresponding to an equilibrium potential for $\mathrm{Cl}^{-}\left(E_{\mathrm{Cl}}\right)$ of $-63 \mathrm{mV}$ even at the peak. Even if the OGD conditions used in our experiments produce a milder depolarization than that observed at physiological temperature, $\mathrm{Cl}^{-}$still would be driven into the cell through any open $\mathrm{Cl}^{-}$channels as long as the $V_{\mathrm{m}}$ is positive to the $E_{\mathrm{Cl}}$.

In contrast, $\mathrm{Cl}^{-}$cotransporters appear to play an important and selective role during the secondary rise in $\left[\mathrm{Cl}^{-}\right]_{i}$. This rise in $\left[\mathrm{Cl}^{-}\right]_{\mathrm{i}}$ was prevented completely by bumetanide and furosemide, whereas the GABA-gated $\mathrm{Cl}^{-}$channel blocker picrotoxin had no effect. Bumetanide was effective at a concentration that selectively blocks NKCC (Payne et al., 2003); because NKCC-1 is the only NKCC isoform expressed in brain (Russell, 2000), it is likely that NKCC-1 activity is primarily responsible for these changes. Indeed, we observed a progressive increase in phosphorylation of NKCC-1 after OGD, which correlated in time with intracellular accumulation of $\mathrm{Cl}^{-}$. Because NKCC-1 activity is thought to be increased by phosphorylation (Darman and Forbush, 2002), it is likely that NKCC-1 phosphorylation during OGD increases $\left[\mathrm{Cl}^{-}\right]_{\mathrm{i}}$. Consistent with this conclusion, Flatman (2005) reported that deoxygenation doubles NKCC-1 activity in ferret erythrocytes. This effect was blocked by a protein kinase inhibitor, indicating that it results from activation of protein kinases. Both oxidative stress response kinase 1 and STE20/SPS1-related proline-alanine-rich kinase (SPAK, also called PASK) bind to NKCC-1 (Piechotta et al., 2002), and expression of dominantnegative SPAK attenuates phosphorylation and activation of NKCC-1 (Dowd and Forbush, 2003). Therefore, activation of one or both of these kinases may be responsible for phosphorylation of NKCC-1 after OGD, yielding the observed influx of $\mathrm{Cl}^{-}$.

Changes in several other $\mathrm{Cl}^{-}$transporters may occur during OGD. Extracellular $\mathrm{K}^{+}$levels rise during and for at least $30 \mathrm{~min}$ after OGD (Taylor et al., 1999), and elevated extracellular $\mathrm{K}^{+}$ could drive $\mathrm{Cl}^{-}$influx via NKCC-1 (Sun and Murali, 1998; Su et al., 2000; Schomberg et al., 2001). In addition, elevated extracellular $\mathrm{K}^{+}$could bring $\mathrm{Cl}^{-}$into neurons by reversing KCC2 (Payne, 1997; DeFazio et al., 2000; Payne et al., 2003). OGD also decreases KCC2 expression in rat hippocampal slices (Galeffi et al., 2004); because KCC2 serves as a major $\mathrm{Cl}^{-}$extrusion mechanism in neurons, its downregulation may compromise recovery of $\mathrm{Cl}^{-}$gradients after OGD. It is probable that KCC2, while downregulated, still contributes to $\mathrm{Cl}^{-}$extrusion. For example, in diazepam-treated hippocampal slices exposed to OGD, KCC2 levels are $55 \%$ of control, yet neurons are completely protected and $\left[\mathrm{Cl}^{-}\right]_{\mathrm{i}}$ apparently is completely restored (Galeffi et al., 2004). Nevertheless, we found that pharmacological inhibition of $\mathrm{Cl}^{-}$ influx via NKCC-1 is sufficient to prevent $\mathrm{Cl}^{-}$increases in mouse hippocampal neurons after OGD. Thus, it appears that the ability of OGD to activate NKCC-1 is the dominant mechanism involved under our conditions.

\section{Consequences of $\left[\mathrm{Cl}^{-}\right]_{\mathrm{i}}$ accumulation}

Although previous studies have indicated that $\left[\mathrm{Cl}^{-}\right]_{\mathrm{i}}$ rises during OGD (Inglefield and Schwartz-Bloom, 1998; Galeffi et al., 2004), the functional consequences of this change have not been examined directly. By manipulating $\left[\mathrm{Cl}^{-}\right]_{\mathrm{i}}$, we have provided two lines of evidence that an elevation in $\left[\mathrm{Cl}^{-}\right]_{\mathrm{i}}$ is both necessary and sufficient to cause neuronal damage caused by OGD. This extends previous indications that rises in $\left[\mathrm{Cl}^{-}\right]_{\mathrm{i}}$ cause neuron loss during excitotoxicity (Rothman, 1985; Choi and Rothman, 1990; Beck et al., 2003). The ability of bumetanide and furosemide to prevent such OGD-induced rises in $\left[\mathrm{Cl}^{-}\right]_{\mathrm{i}}$ during reoxygenation can also explain why these agents are neuroprotective after ischemia (Yan et al., 2001, 2003; Beck et al., 2003; Pond et al., 2004). Neuronal damage could also indirectly arise from OGD-induced damage to glial cells. Elevated $\left[\mathrm{K}^{+}\right]_{\mathrm{o}}$, which can occur after OGD, causes glial cell swelling that is blocked by inhibition of NKCC-1 (Hochman et al., 1999; Su et al., 2002). Although some adult neurons have $\left[\mathrm{Cl}^{-}\right]_{\mathrm{i}}$ comparable with what we observe in hippocampal neurons after OGD (Alvarez-Leefmans et al., 1988, 2001; Sung et al., 2000; Reisert et al., 2005), these neurons may not be damaged because they have protective strategies (e.g., maintaining low $\left[\mathrm{Ca}^{2+}\right]_{\mathrm{i}}$ ).

There are several ways in which elevation of $\left[\mathrm{Cl}^{-}\right]_{\mathrm{i}}$ could produce neuronal damage. The most obvious way is by regulating $\mathrm{Cl}^{-}$flux through $\mathrm{GABA}_{\mathrm{A}}$ receptors. In normal conditions, the resting $V_{\mathrm{m}}$ of CA1 neurons is reported to range between -56 and $-70 \mathrm{mV}$ (Spruston and Johnston, 1992; Shimizu et al., 1996; Perez Velazquez et al., 1997; Tanaka et al., 1999). From our measurements of $\left[\mathrm{Cl}^{-}\right]_{\mathrm{i}}$ under such conditions (5.6 mM) (Fig. $5 F$ ), the Nernst equation indicates that $E_{\mathrm{Cl}}$ would be $-80 \mathrm{mV}$, which would yield an inwardly directed electrochemical gradient for $\mathrm{Cl}^{-}$and a hyperpolarizing, inhibitory response to GABA. Seventy-five minutes into reoxygenation, $\left[\mathrm{Cl}^{-}\right]_{\mathrm{i}}$ is elevated to $>13 \mathrm{~mm}$ (Fig. $5 F$ ), which would shift $E_{\mathrm{Cl}}$ to $-58 \mathrm{mV}$. Other studies have reported that $V_{\mathrm{m}}$ depolarizes early during reoxygenation (Shimizu et al., 1996; Perez Velazquez et al., 1997; Tanaka et al., 1999); if the $V_{\mathrm{m}}$ is positive to $E_{\mathrm{Cl}}$ at these times, GABA receptors and other $\mathrm{Cl}^{-}$-permeable pathways would still produce a hyperpolarizing, inhibitory influx of $\mathrm{Cl}^{-}$. However, if the $V_{\mathrm{m}}$ recovers to values more negative than $-58 \mathrm{mV}$ by $75 \mathrm{~min}$, then GABA would cause $\mathrm{Cl}^{-}$efflux and depolarize the neurons, possibly contributing to neuronal hyperexcitability (Thompson and Gahwiler, 1989; Kaila, 1994) and causing neuronal damage. Independent of an effect on neuronal excitability, elevated $\left[\mathrm{Cl}^{-}\right]_{\mathrm{i}}$ could also contribute to cell swelling by providing an electrical counter ion that cotransports $\mathrm{Na}^{+}$entry into neurons and might have other, unanticipated effects on neuronal viability.

In summary, our findings reveal significant disruptions in $\mathrm{Cl}^{-}$homeostasis after OGD. The OGD-induced increase in $\left[\mathrm{Cl}^{-}\right]_{\mathrm{i}}$ during reoxygenation is likely to be a result of enhanced activity of the $\mathrm{Cl}^{-}$cotransporter NKCC-1. We postulate that NKCC-1 causes accumulation of intracellular $\mathrm{Cl}^{-}$after OGD and other forms of hypoxic injury and that this may play a key role in the neuronal damage that ensues.

\section{References}

Allen NJ, Rossi DJ, Attwell D (2004) Sequential release of GABA by exocytosis and reversed uptake leads to neuronal swelling in stimulated ischemia of hippocampal slices. J Neurosci 24:3837-3849.

Alvarez-Leefmans FJ, Gamino SM, Giraldez F, Nogueron I (1988) Intracellular chloride regulation in amphibian dorsal root ganglion neurons studied with ion-selective microelectrodes. J Physiol (Lond) 406:225-246.

Alvarez-Leefmans FJ, Leon-Olea M, Mendoza-Sotelo J, Alvarez FJ, Anton B, Garduno R (2001) Immunolocalization of the $\mathrm{Na}^{+}-\mathrm{K}^{+}-2 \mathrm{Cl}^{-}$cotrans- 
porter in peripheral nervous tissue of vertebrates. Neuroscience 104:569-582.

Beck J, Lenart B, Kintner DB, Sun D (2003) Na-K-Cl cotransporter contributes to glutamate-mediated excitotoxicity. J Neurosci 23:5061-5068.

Berglund K, Dunbar RL, Lee P, Feng G, Augustine GJ (2004) Imaging synaptic inhibition with Clomeleon, a genetically encoded chloride indicator. In: Imaging in neuroscience and development: a laboratory manual (Yuste R, Konnerth A, eds), pp 595-598. Cold Spring Harbor, NY: Cold Spring Harbor Laboratory.

Bonnet U, Wiemann M, Bingmann D (1998) $\mathrm{CO}_{2} / \mathrm{HCO}_{3}{ }^{-}$-withdrawal from the bath medium of hippocampal slices: biphasic effect on intracellular $\mathrm{pH}$ and bioelectric activity of CA3 neurons. Brain Res 796:161-170.

Boyarsky G, Ganz MB, Sterzel RB, Boron WF (1988) pH regulation in single glomerular mesangial cells. I. Acid extrusion in absence and presence of $\mathrm{HCO}_{3}{ }^{-}$. Am J Physiol 255:C844-C856.

Choi DW, Rothman SM (1990) The role of glutamate neurotoxicity in hypoxic-ischemic neuronal death. Annu Rev Neurosci 13:171-182.

Darman RB, Forbush B (2002) A regulatory locus of phosphorylation in the $\mathrm{N}$ terminus of the Na-K-Cl cotransporter, NKCC1. J Biol Chem 277:37542-37550.

DeFazio RA, Keros S, Quick MW, Hablitz JJ (2000) Potassium-coupled chloride cotransport controls intracellular chloride in rat neocortical pyramidal neurons. J Neurosci 20:8069-8076.

Diarra A, Sheldon C, Brett CL, Baimbridge KG, Church J (1999) Anoxiaevoked intracellular $\mathrm{pH}$ and $\mathrm{Ca}^{2+}$ concentration changes in cultured postnatal rat hippocampal neurons. Neuroscience 93:1003-1016.

Dowd BF, Forbush B (2003) PASK (proline-alanine-rich STE20-related kinase), a regulatory kinase of the $\mathrm{Na}-\mathrm{K}-\mathrm{Cl}$ cotransporter (NKCC1). J Biol Chem 278:27347-27353

Flatman PW (2005) Activation of ferret erythrocyte $\mathrm{Na}^{+}-\mathrm{K}^{+}-2 \mathrm{Cl}^{-} \mathrm{CO}_{-}$ transport by deoxygenation. J Physiol (Lond) 563:421-431.

Flemmer AW, Giménez I, Dowd BFX, Darman RB, Forbush B (2002) Activation of the $\mathrm{Na}-\mathrm{K}-\mathrm{Cl}$ cotransporter NKCC1 detected with a phosphospecific antibody. J Biol Chem 277:37551-37558.

Fukuda A, Tanaka M, Yamada Y, Muramatsu K, Shimano Y, Nishino H (1998) Simultaneous optical imaging of intracellular $\mathrm{Cl}^{-}$in neurons in different layers of rat neocortical slices: advantages and limitations. Neurosci Res 32:363-371.

Galeffi F, Sinnar S, Schwartz-Bloom RD (2000) Diazepam promotes ATP recovery and prevents cytochrome c release in hippocampal slices after in vitro ischemia. J Neurochem 75:1242-1249.

Galeffi F, Sah R, Pond BB, George A, Schwartz-Bloom RD (2004) Changes in intracellular chloride after oxygen-glucose deprivation in the adult hippocampal slice: effect of diazepam. J Neurosci 24:4478-4488.

Hansen AJ (1985) Effect of anoxia on ion distribution in the brain. Physiol Rev 65:101-148.

Hochman DW, D’Ambrosio R, Janigro D, Schwartzkroin PA (1999) Extracellular chloride and the maintenance of spontaneous epileptiform activity in rat hippocampal slices. J Neurophysiol 81:49-59.

Inglefield JR, Schwartz-Bloom R (1998) Optical imaging of hippocampal neurons with a chloride-sensitive dye: early effects of in vitro ischemia. J Neurochem 70:2500-2509.

Jang IS, Jeong HJ, Akaike N (2001) Contribution of the Na-K-Cl cotransporter on $\mathrm{GABA}_{\mathrm{A}}$ receptor-mediated presynaptic depolarization in excitatory nerve terminals. J Neurosci 21:5962-5972.

Kaila K (1994) Ionic basis of $\mathrm{GABA}_{\mathrm{A}}$ receptor channel function in the nervous system. Prog Neurobiol 42:489-537.

Katsura K, Asplund B, Elkholm A, Siesjö BK (1992) Extra- and intracellular $\mathrm{pH}$ in the brain during ischaemia, related to tissue lactate content in normao- and hypercapic rats. Eur J Neurosci 4:166-176.

Kuner T, Augustine G (2000) A genetically encoded ratiometric indicator for chloride: capturing chloride transients in cultured hippocampal neurons. Neuron 27:447-459.

Lipton P (1999) Ischemic cell death in brain neurons. Physiol Rev 79:1432-1538.

Payne JA (1997) Functional characterization of neuronal-specific $\mathrm{K}_{-} \mathrm{Cl}^{-}$ cotransporter: implication for $\left[\mathrm{K}^{+}\right]_{\mathrm{o}}$ regulation. Am J Physiol 42:C1516-C1525.

Payne JA, Rivera C, Voipio J, Kaila K (2003) Cation-chloride co-transporter in neuronal communication, development and trauma. Trends Neurosci 26:199-206.

Perez Velazquez JL, Frantseva MV, Carlen PL (1997) In vitro ischemia pro- motes glutamate-mediated free radical generation and intracellular calcium accumulation in hippocampal pyramidal neurons. J Neurosci 17:9085-9094.

Piechotta K, Lu J, Delpire E (2002) Cation chloride cotransporters interact with the stress-related kinases Ste20-related proline-alanine-rich kinase (SPAK) and oxidative stress response 1 (OSR1). J Biol Chem 277:5081250819.

Pond BB, Galeffi F, Ahrens R, Schwartz-Bloom RD (2004) Chloride transport inhibitors influence recovery from oxygen-glucose deprivation-induced cellular injury in adult hippocampus. Neuropharmacology 47:253-262.

Reisert J, Lai J, Yau K-W, Bradley J (2005) Mechanism of the excitatory $\mathrm{Cl}^{-}$ response in mouse olfactory receptor neurons. Neuron 45:553-561.

Richerson GB, Messer C (1995) Effect of composition of experimental solutions on neuronal solutions on neuronal survival during rat brain slicing. Exp Neurol 131:133-143.

Rothman SM (1985) The neurotoxicity of excitatory amino acids in produced by passive chloride influx. J Neurosci 5:1483-1489.

Russell JM (2000) Sodium-potassium-chloride cotransport. Physiol Rev 80:211-276.

Schlue WR, Deitmer JW (1988) Ionic mechanisms of intracellular pH regulation in the nervous system. Ciba Found Symp 139:47-69.

Schomberg SL, Su G, Haworth RA, Sun D (2001) Stimulation of Na-K-2Cl cotransporter in neurons by activation of non-NMDA ionotropic receptor and group-I mGluRs. J Neurophysiol 85:2563-2575.

Schomberg SL, Bauer J, Kintner DB, Su G, Flemmer A, Forbush B, Sun D (2003) Cross talk between the $\mathrm{GABA}_{\mathrm{A}}$ receptor and the Na-K-Cl cotransporter is mediated by intracellular $\mathrm{Cl}^{-}$. J Neurophysiol 89:159-167.

Shimizu H, Mizuguchi A, Aoki M (1996) Differential responses between CA1 pyramidal cells and granule cells to ischemic insult in rat hippocampal slices. Neurosci Lett 203:195-198.

Slemmer JE, Matsushita S, De Zeeuw CI, Weber JT, Knöpfel T (2004) Glutamate-induced intracellular chloride concentration in hippocampal cell cultures derived from EYFP-expressing mice. Eur J Neurosci 19:2915-2922.

Sömjen GG (2001) Mechanisms of spreading depression and hypoxic spreading depression-like depolarization. Physiol Rev 81:1065-1096.

Spruston N, Johnston D (1992) Perforated patch-clamp analysis of the passive membrane properties of three classes of hippocampal neurons. J Neurophysiol 67:508-529.

Su G, Haworth RA, Dempsey RJ, Sun D (2000) Regulation of $\mathrm{Na}^{+}-\mathrm{K}^{+}-\mathrm{Cl}^{-}$ cotransporter in primary astrocytes by dibutyryl cAMP and high $\left[\mathrm{K}^{+}\right]_{0}$. Am J Phyisol 279:C1710-C1721.

Su G, Kintner DB, Sun D (2002) Contribution of $\mathrm{Na}^{+}-\mathrm{K}^{+}-\mathrm{Cl}^{-}$cotransporter to high- $\left[\mathrm{K}^{+}\right]_{\mathrm{o}}$-induced swelling and EAA release in astrocytes. Am J Physiol Cell Physiol 282:1136-1146.

Sun D, Murali SG (1998) Stimulation of $\mathrm{Na}^{+}-\mathrm{K}^{+}-2 \mathrm{Cl}^{-}$cotransporter in neuronal cells by excitatory neurotransmitter glutamate. Am J Phyisol 175:C772-C779.

Sung KW, Kirby M, McDonald MP, Lovinger DM, Delpire E (2000) Abnormal $\mathrm{GABA}_{\mathrm{A}}$ receptor-mediated currents in dorsal root ganglion neurons isolated from Na-K-2Cl cotransporter null mice. J Neurosci 20:7531-7538.

Tanaka E, Yamamoto S, Kudo Y, Mihara S, Higashi H (1997) Mechanisms underlying the rapid depolarization produced by deprivation of oxygen and glucose in rat hippocampal CA1 neurons in vitro. J Neurophysiol 78:891-902.

Tanaka E, Yamamoto S, Inokuchi H, Isagai T, Higashi H (1999) Membrane dysfunction induced by in vitro ischemia in rat hippocampal CA1 pyramidal neurons. J Neurophysiol 81:1872-1880.

Taylor CP, Weber ML, Gaughan CL, Lehning EJ, LoPachin RM (1999) Oxygen/glucose deprivation in hippocampal slices: altered intraneuronal elemental composition predicts structural and functional damage. J Neurosci 19:619-629.

Thompson SM, Gahwiler BH (1989) Activity-dependent disinhibition. II. Effects of extacellular potassium, furosemide, and membrane potential

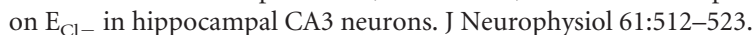

Tombaugh GC (1994) Mild acidosis delays hypoxic spreading depression and improves neuronal recovery in hippocampal slices. J Neurosci 14:5635-5643.

Yan Y, Dempsey RJ, Sun D (2001) $\mathrm{Na}^{+}-\mathrm{K}^{+}-\mathrm{Cl}^{-}$cotransporter in rat focal cerebral ischemia. J Cereb Blood Flow Metab 21:711-721.

Yan Y, Dempsey RJ, Flemmer A, Forbush B, Sun D (2003) Inhibition of $\mathrm{Na}(+)-\mathrm{K}(+)-\mathrm{Cl}(-)$ cotransporter during focal cerebral ischemia decreases edema and neuronal damage. Brain Res 961:22-31. 